\title{
EFFECT OF IRRIGATION METHOD AND QUANTITY ON SQUASH YIELD AND QUALITY
}

\author{
Kamal H. Amer ${ }^{a}$
}

\section{ABSTRACT}

Squash yield and quality under furrow and trickle irrigation methods and their responses to different irrigation quantities were evaluated in 2010 spring and fall seasons. A field experiment was conducted using squash (Cucurbita pepo L.) grown in northern Egypt at Shibin El Kom, Menofia. A Randomized Split-Plot Design was projected with irrigation methods as main plots and different irrigation quantities randomly distributed within either furrow or trickle irrigation methods. Irrigation quantity was a ratio of crop evapotranspiration $\left(E T_{c}\right)$ as: $0.5,0.75,1.0,1.25$, and 1.5 $E T_{c}$. Each treatment was repeated three times, two planting rows from five rows were left for squash seed production. In well-watered conditions $\left(1.0 E T_{c}\right)$, seasonal water usable by squash was 304 and 344 mm over 93 days in spring and 238 and $272 \mathrm{~mm}$ over 101 days in fall under trickle and furrow irrigation methods, respectively. Squash fruit yield and quality were significantly affected by season and both irrigation method and quantity, except fruit number wasn't by irrigation method and its length wasn't affected by season. Interaction between season and irrigation quantity significantly affected leaf area index, TSS, and fruit weight. Moreover, seed yield and quality were significantly changed by season and both irrigation method and quantity, except harvest index wasn't affected by irrigation method. Only a significant interaction between season and irrigation method was for seed yield and 100 seeds weight. Interaction between season and irrigation quantity insignificantly affected seed yield and quality except harvest index. Both fruit and seed yields were significantly affected in a linear relationship $\left(r^{2} \geq 0.91\right)$ by either deficit or surplus irrigation quantities under both irrigation methods. Adequate irrigation quantity under trickle irrigation, relative to that of furrow, enhanced squash yield and improved its quality in both growing seasons.

\footnotetext{
a Department of Agricultural Engineering, Menofia University, Shibin El-Kom, Menofia 32511, Egypt.
} 
Fall season was not appropriate for seed production due to obtaining many of empty seeds caused by low weather parameters at the end of the season. The results from small experiment were extrapolated to big field to find out optimal irrigation scheduling under non-uniformity of irrigation application.

Keywords: Squash yield and quality; Furrow irrigation, trickle irrigation, and scheduling; Crop coefficient.

\section{INTRODUCTION}

T $\mathrm{n}$ Egypt, River Nile which floods about 55 billion $\mathrm{m}^{3}$ water a year is the most important water resources for agricultural, industrial, and urban activities. Rainfall which is about $13 \mathrm{~mm}$ a year and occurs only in winter season is not sufficient even for an irrigation interval. Even though, most of ground water comes due to infiltrating and moving water from Nile or its irrigated fields. More than $85 \%$ of water consumption is due to agricultural related activities. Moreover, a large number of small scale farmers who owns dispersed plots over an area irrigate their crops from small earthen ditches where it is impossible to measure the water used by individual farmers. Farmers rationally endeavor to obtain more water during its flowing in ditches to achieve maximum crop production, but, not all of them can have the same quantity of water under the limited availability of water. Therefore, modern irrigation techniques are demanded in order to use water more efficiently and sustain the increase of both cultivated land and populations.

Squash (Cucurbita pepo L.) is predominantly grown on small fields which are less than 1 ha in spring, summer, and fall seasons. Squash plants grow best on fertile, well drained soil with organic matter. Plants should be irrigated during dry weather. Trickle or furrow irrigation is better than sprinkler irrigation as any moisture on the leaves increases the incidence of leaf disease. The fresh fruits are harvested 40 days after planting when they are small and tender $(3-5 \mathrm{~cm}$ in diameter) before the rind hardens; therefore, they should be harvested two or three times a week. But, seed yield is harvested at the end of the season. Squash is sensitive to, and may be damaged by, excessive soil water from seed sowing to emergence. Since squash rooting depth is relatively shallow, 
soil water has to be maintained above $50 \%$ of the available soil water capacity in order to avoid detrimental water deficit (Mario et al., 1997). Squash roots, most of which are in the top of $40-50 \mathrm{~cm}$ of soil, develop rapidly. Irrigation should be scheduled to avoid excessive moisture or water stress. Lack of adequate soil water at harvest can result in misshapen fruits, but too much soil water can aggravate root and stem rot diseases (Richard et al., 2002).

Considering all other factors of production at their optimum level, crop response is defined as a crop yield decreased constantly by decreasing quantity of water applied into the root zone in deficit irrigation (Richard et al., 2002; Amer, 2010); nevertheless, crop yield is decreased constantly by increasing quantity of water applied in surplus irrigation. The relationship between crop yield and irrigation quantity can be found from irrigation experiments in which a large range of irrigation application is conducted. Ahmet et al. (2004) using furrow irrigation on squash (Cucurbita pepo L.) found that fruit yield was significantly increased in linear relationship from 22.4 to $44.7 \mathrm{Mg} \mathrm{ha}^{-1}$ as irrigation water applied increased from 279 to $475 \mathrm{~mm}$ in deficit irrigation where no deep percolation is occurred.

Al-Omran et al. (2005) studied squash (Cucurbita pepo L.) using both surface (DI) and subsurface drip irrigations (SDI) in sandy soils with three clay deposits found that fruit yield has a linear relationship to increasing irrigation water level for each season within the same treatment. They found that fruit yields significantly increased with clay deposits compared with control. The differences between SDI and DI on fruit yields were also significant. Water use efficiency linearly increased as irrigation water applied increased for deficit irrigation level and decreased for excessive irrigation level.

Amer (2010) working on corn (Zea Mays) irrigated by furrow found that maximum yield $\left(\mathrm{Y}_{\mathrm{m}}\right)$ of $9.12 \mathrm{Mg} \mathrm{ha}^{-1}$ was achieved by $325 \mathrm{~mm}$ adequate irrigation quantity $(\mathrm{d})$. A yield reduction $\left(1-\mathrm{Y} / \mathrm{Y}_{\mathrm{m}}\right)$ was linearly decreased in a rate of 1.15 by increasing water deficit fraction $(1-\mu / d)$ in complete deficit irrigation in range of 0.6 to $1.0 \mathrm{ET}_{\mathrm{c}}$, where $\mathrm{Y}$ is the corresponding yield achieved by irrigation quantity $\mu$. He found that the crop yield was linearly decreased in surplus areas by increasing irrigation water quantity 
ranged from 1.0 to $1.4 \mathrm{ET}_{\mathrm{c}}$ in a rate of 0.32 . Furthermore, an optimal irrigation scheduling is statistically developed based on crop response to extrapolate data from the small experiment (uniform condition) to big field (non-uniformity condition) under the experiment constraints.

The purpose of the research was to study squash crop response to different irrigation quantities under both furrow and trickle irrigation systems. A goal of the study is to utilize optimal irrigation scheduling in order to obtain a maximum crop yield in theoretical non-uniformity of water application.

\subsection{Field experimental work \\ MATERIALS AND METHODS}

Squash (Cucurbita pepo L.) was grown in 2010 spring and fall seasons in clay soil located at an arid site in northern Egypt (Shibin El-Kom area, $17.9 \mathrm{~m}$ above sea level, $30^{\circ} 32^{\prime} \mathrm{N}, 31^{\circ} 03^{\prime} \mathrm{E}$ ). The crop was planted on 16 March and 18 August, and terminated on 17 June and 27 November in the 2010 spring and fall seasons, respectively. A Randomized Split Plot design with irrigation method treatments as main plots and irrigation quantities as random treatments within an irrigation method was established (Fig. 1). Each treatment was repeated three times, two planting rows from five rows were left for squash seed production. Plot size for an irrigation method was $18 \times 27 \mathrm{~m}$ with $0.5 \mathrm{~m}$ row width, and an about $0.5 \mathrm{~m}$ spacing between plants within rows. Squash seeds were sown with a seed to each hole. All treatments were separated as surrounded by $1 \mathrm{~m}$ non-irrigated area as shown in Fig. 1. Plants were adequately watered in first irrigation. Irrigation quantity treatments were initiated at the second irrigation. Furrow and trickle irrigation systems were represented the irrigation method treatments. Irrigation quantity treatments were rated as $0.5,0.75,1.0,1.25$, and $1.5 \mathrm{ET}_{\mathrm{c}}$, where $\mathrm{ET}_{\mathrm{c}}$ is crop evpotranspiration. Irrigation water was applied when volumetric soil moisture content reached in between 0.318 and $0.354 \mathrm{~m}^{3} \mathrm{~m}^{-3}$ in the upper $0.5 \mathrm{~m}$ of soil profile for $1.0 \mathrm{ET}_{\mathrm{c}}$ treatment. Soil moisture sensors were set in each $1.0 \mathrm{ET}_{\mathrm{c}}$ replicate and calibrated by taken soil samples. Sensors were vertically installed at 0-10, 10-20, 20-30, 30-40, 40-50, and 50-60 cm depths. They were horizontally installed at $0,10,20,30,40$, and 50 
$\mathrm{cm}$ for each $10 \mathrm{~cm}$ vertical soil depth. Sensors readings each experimental plot were monitored before and after irrigation in both methods. But, readings were taken in between two following irrigations only for furrow method. Readings were taken after $36 \mathrm{~h}$ from irrigation to draw soil-water redistribution under both furrow and trickle irrigations. Sensor readings were taken before irrigation to a depth of $0.6 \mathrm{~m}$ to determine water usable by plant. But, irrigation schedule was to refill the $0.5 \mathrm{~m}$ depth of root zone until soil reached field capacity $\left(0.423 \mathrm{~m}^{3} \mathrm{~m}^{-3}\right)$ point. Irrigation scheduling for $0.5,0.75,1.25$, and $1.5 \mathrm{ET}_{\mathrm{c}}$ treatments were fractioned from $1.0 \mathrm{ET}_{\mathrm{c}}$ for each irrigation method. In the experimental site, there was no rainfall or ground water contribution, which water table was greater than $2.8 \mathrm{~m}$, during the study period.

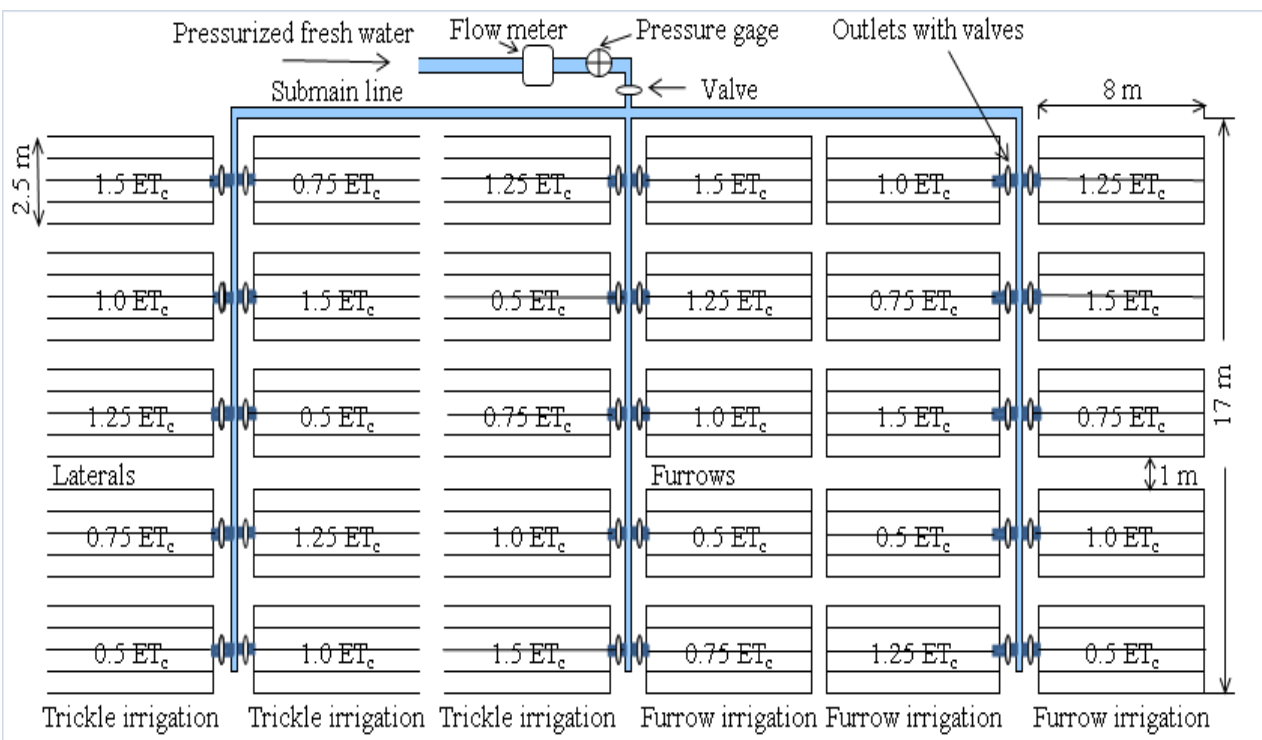

Fig. 1. Split plot experimental design for combination of irrigation methods and quantities in 2010 summer and fall seasons

Furrow and trickle irrigation systems were installed before planting in the experiment. The control unit of both irrigation systems consisted of a pressurized water resource, flow meter, pressure gage, and control valves (Fig. 1). Furrow width was $1 \mathrm{~m}$ and planted by two rows of squash. Emitters with $4 \mathrm{l} / \mathrm{h}$ flow rate at $101 \mathrm{kPa}$ pressure were spaced $0.5 \mathrm{~m}$ on trickle lateral. A trickle line for each plant row and an emitter for each squash plant were used in the experiment. Farmyard manure was added as $17 \mathrm{Mg} \mathrm{ha}^{-1}$ before squash sowing. Chemical fertilizer quantity added 
to the experiment was the recommended rate for squash production in this area, $150 \mathrm{~kg} \mathrm{ha}^{-1} \mathrm{~N}, 60 \mathrm{~kg} \mathrm{ha}^{-1} \mathrm{P}$, and $70 \mathrm{~kg} \mathrm{ha}^{-1} \mathrm{~K}$ which was added at squash sowing, flowering, and fruiting stages.

Soil was classified as clay with $1.28 \mathrm{~g} \mathrm{~cm}^{-3}$ bulk density, non-saline and non-alkaline $\left(\mathrm{EC}_{\mathrm{e}}=2 \mathrm{dS} / \mathrm{m}, \mathrm{SAR}=7.5\right.$, and $\left.\mathrm{pH}=7.6\right)$. The studied area was irrigated by pressurized fresh water having $\mathrm{EC}=0.85, \mathrm{SAR}=2.8$, and $\mathrm{pH}=8.2$. Soil particle sizes for $0.6 \mathrm{~m}$ of soil profile were distributed as $17.8 \%$ sand, $31.13 \%$ silt, and $51.07 \%$ clay. The volumetric water content values were measured using pressure membrane as $65.7,42.3$, and $21.3 \%$ at saturated, field capacity, and wilting points, respectively. Soil infiltration was measured in the upper $30 \mathrm{~cm}$ of soil surface using double ring infiltrometer. An average value of minimum infiltration rate which considered as saturated hydraulic conductivity $\left(\mathrm{k}_{\mathrm{s}}\right)$ was recorded as $28.2 \mathrm{~mm} \mathrm{~h}^{-1}$ for pretreatments.

The adequate irrigation quantity ( $\mathrm{d}$ for each $1.0 \mathrm{ET}_{\mathrm{c}}$ treatment) to be applied was determined in millimeters per irrigation interval based on the average of volumetric moisture content of soil root depth before and after irrigation under both furrow and trickle irrigation methods as follows:

$$
d=\left(\theta_{f_{c}}-\theta_{i}\right) D P
$$

where $\mathrm{d}$ is scheduling irrigation depth $(\mathrm{mm}), \theta_{\mathrm{fc}}$ and $\theta_{\mathrm{i}}$ are, respectively, soil moisture content at field capacity and initiation $\left(\mathrm{m}^{3} \mathrm{~m}^{-3}\right), \mathrm{D}$ is wetted soil root depth $(\mathrm{mm})$, and $\mathrm{P}$ is wetted volume fraction. $\mathrm{P}$ was derived in this study as follows:

$$
P=\frac{\theta_{f}-\theta_{i}}{\theta_{f_{c}}-\theta_{i}}
$$

where $\theta_{\mathrm{f}}$ is final volumetric moisture content after soil-water redistribution in projected soil volume per squash plant. For an irrigation method and $1.0 \mathrm{ET}_{\mathrm{c}}$ treatment, soil samples and sensor readings were taken from each replicate before and after irrigation to determine the average of soil water content $\left(\theta_{\mathrm{f}}\right.$ and $\left.\theta_{\mathrm{i}}\right)$. Equation 1 was used to determine water applied as multiplying $0.5 \mathrm{~m}$ depth by its soil moisture deficit before and after irrigation in the same day. It was also used to determine water used by squash as multiplying $0.6 \mathrm{~m}$ soil depth by its moisture deficit during interval between two irrigation dates. 
Reference evapotranspiration $\left(\mathrm{ET}_{\mathrm{o}}\right)$ was determined from weather data collected at Shibin El Kom area using FAO Penman-Monteith modified by Allen et al. (1998). Meteorological elements (temperatures, relative humidity, wind speed, and radiation) were measured in experimental area by an automatic weather station as described by Amer (2004). Weather data, $\mathrm{ET}_{\mathrm{o}}$, and Class $\mathrm{A}$ pan evaporation $\left(\mathrm{E}_{\mathrm{p}}\right)$ were monthly shown in Table 1. Squash average crop coefficient per interval was found by dividing water usable by squash by $\mathrm{FAO}_{\mathrm{ET}}$ for each irrigation interval in 2010 spring and fall seasons.

Table 1. Meteorological data at Shibin El-Kom, Egypt during 2010 spring and fall growing seasons.

\begin{tabular}{lccccccccc}
\hline Month & $\begin{array}{c}\mathrm{T}_{\text {avg }} * \\
{ }^{\circ} \mathrm{C}\end{array}$ & $\begin{array}{c}\mathrm{T}_{\max } \mathrm{C} \\
{ }^{\circ} \mathrm{C}\end{array}$ & $\begin{array}{c}\mathrm{T}_{\min } \\
{ }^{\circ} \mathrm{C}\end{array}$ & $\begin{array}{c}\mathrm{RH}_{\text {avg }} \\
\%\end{array}$ & $\begin{array}{c}\mathrm{U}_{2} \\
\mathrm{~m} \mathrm{~s}^{-1}\end{array}$ & $\begin{array}{c}\mathrm{R}_{\mathrm{s}} \\
\mathrm{MJ} \mathrm{m}^{-2} \mathrm{~d}^{-1}\end{array}$ & $\begin{array}{c}\mathrm{R}_{\mathrm{n}} \\
\mathrm{MJ} \mathrm{m}^{-2} \mathrm{~d}^{-1}\end{array}$ & $\begin{array}{c}\mathrm{ET}_{\mathrm{o}} \\
\mathrm{mm} \mathrm{d}^{-1}\end{array}$ & $\begin{array}{c}\mathrm{E}_{\mathrm{p}} \\
\mathrm{mm} \mathrm{d}^{-1}\end{array}$ \\
\hline March & 19.69 & 28.53 & 12.48 & 63.0 & 0.60 & 19.79 & 10.45 & 3.19 & 4.96 \\
April & 21.56 & 29.59 & 14.55 & 53.2 & 0.72 & 23.38 & 12.84 & 4.17 & 6.25 \\
May & 25.64 & 34.29 & 17.45 & 46.5 & 0.89 & 25.00 & 14.36 & 5.16 & 7.80 \\
June & 27.14 & 34.87 & 19.92 & 53.0 & 0.67 & 25.47 & 15.35 & 5.26 & 8.32 \\
July & 28.01 & 34.99 & 22.13 & 63.2 & 0.62 & 22.87 & 14.26 & 4.79 & 7.68 \\
Aug. & 28.85 & 35.76 & 23.05 & 61.7 & 0.51 & 20.93 & 12.65 & 4.32 & 7.25 \\
Sept. & 27.49 & 35.79 & 20.62 & 58.8 & 0.50 & 20.25 & 11.38 & 3.90 & 6.72 \\
Oct. & 23.45 & 31.44 & 16.85 & 60.7 & 0.56 & 15.58 & 8.61 & 2.90 & 4.50 \\
Nov. & 20.53 & 28.08 & 14.65 & 64.6 & 0.57 & 11.66 & 5.81 & 1.94 & 3.01 \\
\hline
\end{tabular}

$* \mathrm{~T}_{\text {avg }}, \mathrm{T}_{\max }$, and $\mathrm{T}_{\min }$ are monthly average, maximum, and minimum temperatures, respectively, $\mathrm{RH}_{\text {avg }}$ is monthly average relative humidity, $\mathrm{U}_{2}$ is monthly average wind speed, $\mathrm{R}_{\mathrm{s}}$ is monthly average solar radiation, $\mathrm{R}_{\mathrm{n}}$ is monthly average net radiation determined according to Allen et al. (1998) , $\mathrm{ET}_{\mathrm{o}}$ is monthly average potential evapotranspiration (Allen et al. (1998), and $\mathrm{E}_{\mathrm{P}}$ is monthly average of measured pan evaporation class A.

Leaf area per plant was periodically measured along 2010 spring and fall growing seasons in field situation using planometer. Leaf area was reported as the average of three measurements per replicate. Leaf area index (LAI) was determined by dividing plant leaf area per its projected area. Sixty two days after planting for each season, three plants were taken off by hand from each replicate. Fruit yields were separated from its plants which both individually dried in the oven at $70{ }^{\circ} \mathrm{C}$ until achieving constant weight to determine the dry weight. Likewise, at the end of each season, three plants were sampled each replicate from plant rows which was left for seed production to determine seed yield and total biomass in dry basis. Seed yield was adjusted to $15.5 \%$ moisture content. Dry matter of plant and its components were considered as plant total 
soluble solid (TSS). Harvest index (HI) was determined as a ratio of squash fruit or seed yields to total biomass production on a dry basis. Moreover, fresh fruit weight, number, diameter, and length, and 100 seeds weight and germination percentage were evaluated for each replicate.

The statistical analysis of the experimental data was carried out using the Statistical Analysis System (SAS Institute, 2003). Measured data were analyzed by ANOVA. Duncan's method was statistically used to find out the differences among means. Significance evaluation was hypothesized based on $5 \%$ significant level $(\mathrm{p} \leq 0.05)$.

\subsection{Theoretical application in non-uniformity condition}

Non-uniformity of water application under irrigation system creates both deficit and surplus irrigation areas. In non-uniformity condition, the crop yield was decreased by both water deficit and surplus areas. The relative yield under any irrigation system which creates non-uniformity conditions in the big field was expressed after Amer (2010) as follows:

$$
1-\frac{Y}{Y_{m}}=k_{y 1}\left(1-\frac{\mu_{D}}{d}\right)(1-p)+k_{y 2}\left(\frac{\mu_{S}}{d}-1\right) p
$$

where $Y_{m}$ is maximum yield occurred by adequate irrigation applied (d) in uniformity condition, $\mathrm{Y}$ is total yield under non-uniformity condition or by only either deficit $\left(\mu_{D}\right)$ or surplus $\left(\mu_{S}\right)$ irrigation quantities, and $p$ is surplus area fraction. Surplus area fraction (p) is zero in complete deficit irrigation, but, $\mathrm{p}$ is one in complete surplus irrigation.

Surplus area fraction (p) is derived in this study according to analysis using linear distribution done by Amer (2010) in non-uniformity condition as follows:

$$
p=0.5-\frac{0.29}{C V}\left(\frac{d}{\mu}-1\right)
$$

where $\mathrm{CV}$ is coefficient of variation of irrigation applications and $\mu$ is average of irrigation applications along furrow or trickle lateral.

Average of both deficit $\left(\mu_{\mathrm{D}}\right)$ and surplus $\left(\mu_{\mathrm{S}}\right)$ irrigation applications are, respectively, determined as follows:

$$
\mu_{D}=\frac{d+\mu_{\min }}{2} \quad \text { (5) } \quad \mu_{S}=\frac{d+\mu_{\max }}{2}
$$

where $\mu_{\min }$ and $\mu_{\max }$ are, respectively, minimum and maximum of irrigation applications. 
Distance from centre of furrow bottom $(\mathrm{cm})$

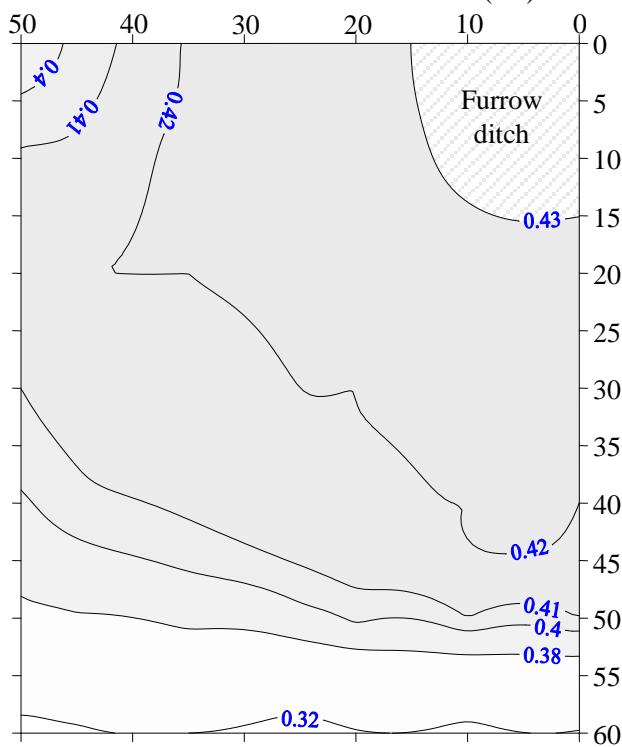

Fig. 2. Volumetric moisture content after soil-water redistribution under furrow irrigation with $74 \mathrm{~mm}$ infiltrated irrigation depth.

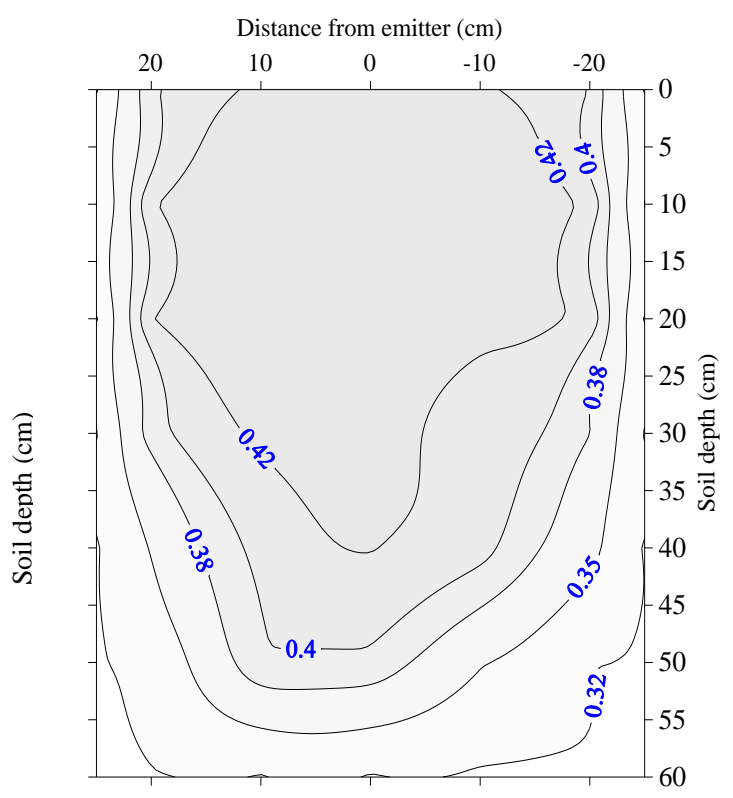

Fig. 3. Volumetric moisture content after soil-water redistribution under trickle irrigation with $4 \mathrm{l} / \mathrm{h}$ emitter flow rate and $1.25 \mathrm{~h}$ flowing.

\section{RESULTS AND DISCUSSION}

\subsection{Wetted soil volume and fraction}

Wetted soil patterns after soil-water redistribution were experimentally found for furrow and trickle irrigations as presented, respectively, in Figs. 2 and 3. It obvious that wetted soil depth was confined to be in root zone by controlling both irrigation quantity and interval. In furrow irrigation (Fig. 2) with applying $47 \mathrm{~mm}$ infiltrated irrigation depth in clay soil which was initialized at $0.32 \mathrm{~m}^{3} \mathrm{~m}^{-3}$ moisture content, volumetric soil moisture contours in $0.282 \mathrm{~m}^{2}$ whole vertical area were distributed from 0.43 to 0.42 in $0.112 \mathrm{~m}^{2}, 0.42$ to 0.41 in $0.078 \mathrm{~m}^{2}, 0.41$ to 0.38 in $0.045 \mathrm{~m}^{2}$, and less than 0.38 in $0.047 \mathrm{~m}^{2}$ vertical soil area. Final volumetric soil moisture content in $0.25 \mathrm{~m}^{2}$ vertical root zone area was averaged as 0.41 . Therefore, wetted soil area fraction related to squash projected area in furrow treatment was 0.92 as calculated from Eq. 2. In trickle irrigation (Fig. 3) with applying 4 l/h emitter flow rate for $1.28 \mathrm{~h}$ operating duration with $0.35 \mathrm{~m}^{3} \mathrm{~m}^{-3}$ initial soil moisture content, volumetric moisture content contours after soil water redistribution was drawn in $0.15 \mathrm{~m}^{3}$ total volume as from 0.43 to 0.42 for $0.034 \mathrm{~m}^{3}, 0.42$ to 0.40 for $0.017 \mathrm{~m}^{3}, 0.40$ to 0.38 for $0.011 \mathrm{~m}^{3}, 0.38$ to 0.35 for $0.016 \mathrm{~m}^{3}$, 
and less than 0.35 for $0.072 \mathrm{~m}^{3}$. For a $0.125 \mathrm{~m}^{3}$ upper wetted soil volume, final soil moisture was averaged as $0.391 \mathrm{~m}^{3} \mathrm{~m}^{-3}$. Therefore, wetted soil volume fraction was determined as 0.562 in trickle irrigation. It seemed that wetted soil volume was symmetrically infiltrated along furrow line, but, it was smoothly surrounded the trickle source. Thus, wetted soil fraction was determined based on vertical area along furrow and volume under trickle emitter.

\subsection{Irrigation practice and squash crop coefficient}

In adequately watered conditions (1.0 $\mathrm{ET}_{\mathrm{c}}$ treatment), squash irrigation based on soil water content under furrow and trickle irrigations as shown in Tables 2 and 3 was scheduled for each interval in both 2010 spring and fall seasons, respectively. Soil root zone was refilled by irrigation water quantity to wet the upper $0.5 \mathrm{~m}$ soil depth at field capacity point; therefore, most of irrigation water applied was confined in $0.5 \mathrm{~m}$ soil surface for considered irrigation interval. It seemed that irrigation started when soil moisture content reached in between 0.318 and $0.354 \mathrm{~m}^{3} \mathrm{~m}^{-3}$ to avoid yield reduction. In inadequately watered conditions, irrigation water applied was adjusted using $0.5,0.75,1.25$, and $1.5 \mathrm{ET}_{\mathrm{c}}$ ratios from total irrigation water applied started from second irrigation. Irrigation water applied was determined (Eqs. 1 and 2) as shown in Tables 2 and 3. Water used by plant was determined per interval using water balance as multiplying volumetric soil moisture deficit occurred between two irrigation dates by effective root zone depth where samples or readings were taken. Number of irrigations with the trickle system was twice that of the furrow irrigation. For adequate condition (1.0 ET $\left.\mathrm{ET}_{\mathrm{c}}\right)$, seasonal irrigation quantity was, respectively, applied in spring and fall seasons as 312 and $251 \mathrm{~mm}$ under trickle irrigation and 373 and $284 \mathrm{~mm}$ under furrow irrigation. Seasonal water usable, respectively, by squash was 304 and $238 \mathrm{~mm}$ for trickle irrigation 344 and $272 \mathrm{~mm}$ for furrow irrigation. It seemed that squash plants consumed less water under trickle irrigation, relative to that of furrow irrigation, suggesting that high evaporation caused from wetted soil surface in early growth stages was higher in furrow irrigation. Moreover, irrigation requirements were significantly increased in spring season, relative to those in fall season, due to increasing weather factors during spring growing season as shown in Table 1. 
Table 2. Squash irrigation applied, used, and crop coefficient in 2010 spring season for 1.0 $\mathrm{ET}_{\mathrm{c}}$.

\begin{tabular}{|c|c|c|c|c|c|c|c|c|c|}
\hline \multirow{2}{*}{$\begin{array}{l}\text { Irrigation } \\
\& \\
\text { reading } \\
\text { date }\end{array}$} & \multicolumn{2}{|c|}{$\begin{array}{c}\dagger \text { Soil } \\
\text { moisture } \\
\text { content }\left(\mathrm{m}^{3} \mathrm{~m}^{-}\right. \\
\left.{ }^{2}\right)\end{array}$} & \multicolumn{2}{|c|}{$\begin{array}{l}\text { Water applied } \\
\text { (mm/irrigation) }\end{array}$} & \multicolumn{2}{|c|}{$\begin{array}{c}\text { Water usable by } \\
\text { plant }(\mathrm{mm})\end{array}$} & \multirow{2}{*}{$\begin{array}{c}\text { FAO } \\
\text { ET } \\
(\mathrm{mm})\end{array}$} & \multicolumn{2}{|c|}{$\begin{array}{c}\text { Crop } \\
\text { coefficient } \mathrm{k}_{\mathrm{c}}\end{array}$} \\
\hline & Trickle & Furrow & Trickle & Furrow & Trickle & Furrow & & Trickle & Furrow \\
\hline 16-March & 0.289 & 0.289 & 37.65 & 61.64 & & & Seedling & & \\
\hline 3-April & 0.339 & 0.340 & 23.60 & 38.18 & 23.60 & 38.18 & 53.79 & 0.44 & 0.71 \\
\hline 13-April & 0.353 & 0.370 & 19.67 & -- & 19.67 & 24.38 & 34.00 & 0.58 & 0.72 \\
\hline 21-April & 0.347 & 0.320 & 21.36 & 47.38 & 21.36 & 23.00 & 27.12 & 0.79 & 0.85 \\
\hline 27-April & 0.345 & 0.368 & 21.92 & -- & 21.92 & 25.30 & 24.25 & 0.90 & 1.04 \\
\hline 2-May & 0.350 & 0.320 & 20.51 & 47.38 & 20.51 & 22.08 & 21.06 & 0.97 & 1.05 \\
\hline 7-May & 0.344 & 0.372 & 22.20 & -- & 22.20 & 23.46 & 21.54 & 1.03 & 1.09 \\
\hline 11-May & 0.341 & 0.318 & 23.04 & 48.30 & 23.04 & 24.84 & 22.79 & 1.01 & 1.09 \\
\hline 16-May & 0.353 & 0.377 & 19.67 & -- & 19.67 & 21.16 & 19.16 & 1.03 & 1.10 \\
\hline 21-Маy & 0.349 & 0.328 & 20.79 & 43.70 & 20.79 & 22.54 & 20.51 & 1.01 & 1.10 \\
\hline 25-May & 0.351 & 0.377 & 20.23 & -- & 20.23 & 21.16 & 19.64 & 1.03 & 1.08 \\
\hline 29-May & 0.357 & 0.334 & 18.55 & 40.94 & 18.55 & 19.78 & 19.24 & 0.96 & 1.03 \\
\hline 2-June & 0.358 & 0.380 & 18.27 & -- & 18.27 & 19.78 & 20.44 & 0.89 & 0.97 \\
\hline 9-June & 0.335 & 0.322 & 24.73 & 45.45 & 24.73 & 26.68 & 34.51 & 0.72 & 0.77 \\
\hline 17-June & 0.318 & 0.354 & Season & end & 29.51 & 31.74 & 48.46 & 0.61 & 0.65 \\
\hline 93 & Seasona & 1 value & 312.2 & 373.0 & 304.0 & 344.08 & 386.5 & 0.79 & 0.89 \\
\hline
\end{tabular}

$\dagger$ It was averaged for $0.5 \mathrm{~m}$ squash root zone and it was not changed beyond this depth.

In well watered condition (1.0 ET $\mathrm{ET}_{\mathrm{c}}$ ), squash crop coefficient $\left(\mathrm{k}_{\mathrm{c}}\right)$ under furrow and trickle irrigations was determined as the ratio of actual $\left(\mathrm{ET}_{\mathrm{c}}\right)$ to reference $\left(\mathrm{ET}_{\mathrm{o}}\right)$ evapotranspiration for the 2010 spring and fall growing seasons (Tables 2 and 3). The initial values of $k_{c}$ were significantly reduced under trickle irrigation compared with furrow in early vegetative stage due to increasing soil evaporation along furrow. Crop coefficient in full vegetative stage was around one and insignificantly increased under furrow irrigation compared to trickle irrigation. Values of $\mathrm{k}_{\mathrm{c}}$ were decreased during the senescence phase at the end of both seasons because of senescing leaves. For a given 1.0 $\mathrm{ET}_{\mathrm{c}}$ treatment, seasonal crop coefficient in spring and fall seasons was, respectively, found almost as 0.79 and 0.75 under trickle irrigation and 0.89 and 0.86 under furrow irrigation. It was evident that seasonal $\mathrm{k}_{\mathrm{c}}$ values by furrow irrigation, relative to those of trickle irrigation, were significantly increased due to increasing wetted soil volume where soil evaporation was enhanced along season. $\mathrm{k}_{\mathrm{c}}$ was insignificantly affected by season. 
Table 3. Squash irrigation applied, used, and crop coefficient in 2010 fall season for $1.0 \mathrm{ET}_{\mathrm{c}}$.

\begin{tabular}{|c|c|c|c|c|c|c|c|c|c|}
\hline \multirow{2}{*}{$\begin{array}{l}\text { Irrigation } \\
\text { or reading } \\
\text { date }\end{array}$} & \multicolumn{2}{|c|}{$\begin{array}{l}\dagger \text { Soil moisture } \\
\text { content }\left(\mathrm{m}^{3} \mathrm{~m}^{-3}\right)\end{array}$} & \multicolumn{2}{|c|}{$\begin{array}{c}\text { Water applied } \\
\text { (mm/irrigation) }\end{array}$} & \multicolumn{2}{|c|}{$\begin{array}{c}\text { Water usable by } \\
\text { plant }(\mathrm{mm})\end{array}$} & \multirow{2}{*}{$\begin{array}{c}\text { FAO } \\
\text { ET } \\
(\mathrm{mm})\end{array}$} & \multicolumn{2}{|c|}{$\begin{array}{c}\text { Crop } \\
\text { coefficient } k_{c}\end{array}$} \\
\hline & Trickle & Furrow & Trickle & Furrow & Trickle & Furrow & & Trickle & Furrow \\
\hline 18-Aug & 0.293 & 0.289 & 36.53 & 61.64 & & & eedling & & \\
\hline 1-Sep & 0.336 & 0.335 & 24.45 & 40.48 & 24.45 & 40.48 & 58.73 & 0.42 & 0.69 \\
\hline 8-Sep & 0.350 & 0.368 & 20.51 & -- & 20.51 & 25.30 & 33.72 & 0.61 & 0.75 \\
\hline 15-Sep & 0.350 & 0.318 & 20.51 & 48.30 & 20.51 & 23.00 & 28.67 & 0.72 & 0.80 \\
\hline 22-Sep & 0.342 & 0.366 & 22.76 & -- & 22.76 & 26.22 & 27.10 & 0.84 & 0.97 \\
\hline 27-Sep & 0.354 & 0.323 & 19.39 & 46.00 & 19.39 & 19.78 & 18.94 & 1.02 & 1.04 \\
\hline 3-Oct & 0.352 & 0.378 & 19.95 & -- & 19.95 & 20.70 & 19.69 & 1.01 & 1.05 \\
\hline 9-Oct & 0.347 & 0.331 & 21.36 & 42.32 & 21.36 & 21.62 & 20.65 & 1.03 & 1.05 \\
\hline $16-O c t$ & 0.346 & 0.374 & 21.64 & -- & 21.64 & 22.54 & 21.29 & 1.02 & 1.06 \\
\hline 26-Oct & 0.345 & 0.324 & 21.92 & 45.54 & 21.92 & 23.00 & 22.80 & 0.96 & 1.01 \\
\hline 9-Nov & 0.345 & 0.370 & 21.92 & -- & 21.92 & 24.38 & 29.63 & 0.74 & 0.82 \\
\hline 27-Nov & 0.340 & 0.316 & \multicolumn{2}{|c|}{ Season end } & 23.32 & 24.84 & 35.10 & 0.66 & 0.71 \\
\hline 101 & \multicolumn{2}{|c|}{ Seasonal value } & 250.9 & 284.3 & 237.7 & 271.9 & 316.3 & 0.75 & 0.86 \\
\hline
\end{tabular}

$\dagger$ It was averaged for $0.5 \mathrm{~m}$ squash root zone and it was not changed beyond this depth.

\subsection{Leaf area index (LAI)}

Leaf area indices were significantly affected by 2010 spring and fall growing seasons (Fig. 4) under both trickle and furrow irrigation methods for $1.0 \mathrm{ET}_{\mathrm{c}}$ treatment. Leaf area showed rapid increases in early growth stages. Leaf area decreased in maturity stage because of senescing leaves in the lower part of the canopy. Vegetative growth was larger during fall that had less radiation and shorter day lengths compared to the spring planting. LAI increased more rapidly in the fall compared to the spring season (Fig. 4). Amer and Hatfield (2004) also reported similar findings earlier. LAI had the greatest increase under trickle irrigation compared with furrow irrigation. Similar results were obtained by Malash et al. (2005) working on tomato. Maximum LAI was achieved near mid-point for both growing seasons. Leaf area index (LAI measured at full growth) differences were significant between the two growing seasons since there was less solar radiation in fall compared to spring (Table 4 for fresh fruit yield plants and Table 8 for seed yield plants). For a given irrigation method, LAI showed significant differences among irrigation quantities $\left(\mathrm{ET}_{\mathrm{c}}\right)$ at $5 \%$ level. LAI for fresh fruit and seed plants showed significant differences between trickle and furrow irrigation methods (Tables 4, 5, 8, and 9). The results in Tables 5 and 9 showed interaction only between season and ET for LAI values. For a given irrigation method in fall season, the highest LAI's were obtained when water was excessively 
applied (1.5 $\mathrm{ET}_{\mathrm{c}}$ treatment). These results are in agreement with those of Amer (2010) working on corn (Zea Mays). For a given treatment, similar results were obtained for LAI's of both fresh fruit and seed productions.

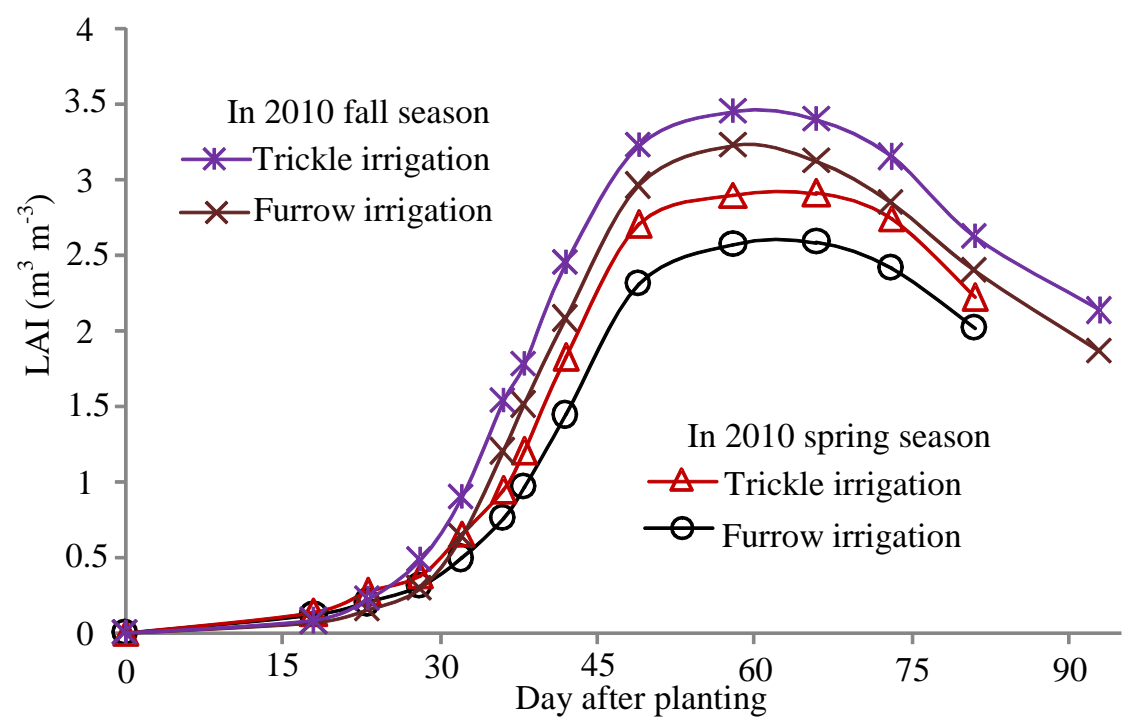

Fig. 4. Leaf area index (LAI) under adequate irrigation (1.0 $\left.\mathrm{ET}_{\mathrm{c}}\right)$ application.

\subsection{Fresh fruit crop response}

A squash fresh fruit yield related to its corresponding uniform irrigation water applied depth was found under trickle and furrow irrigations in 2010 spring and fall seasons as shown in Fig. 5. It decreased as water applied decreased in deficit irrigation due to plant stress causing by drier soil. After that, it decreased as irrigation water quantity increased in surplus irrigation due to over wetting stress on plant roots, causing more vegetative growth, and may be attributed to leaching some fertilizers from root zone. The same conclusion was also obtained by Wan et al. (2010) working on cucumber who found that cucumber yield was greatly decreased due to oxygen deficiency in the soil and waterlogging. For an adequate irrigation quantity $\left(1.0 \mathrm{ET}_{\mathrm{c}}\right)$, maximum fruit yield values were 45.677 and $43.96 \mathrm{Mg} \mathrm{ha}^{-1}$ in spring season and 39.28 and $33.96 \mathrm{Mg} \mathrm{ha}^{-1}$ in fall season under trickle and furrow irrigation methods, respectively. Squash fruit yield was significantly enhanced under trickle irrigation compared with furrow irrigation because irrigation water and fertilizer were uniformity concentrated around plant roots. The conclusion was 
also reported by Hassanli et al. (2010) working on sugar beet under both furrow and trickle irrigations. However, irrigation quantity was significantly reduced by either trickle irrigation or fall season. A fruit yield reduction $\left(1-\mathrm{Y}_{\mathrm{m}} \mathrm{Y}_{\mathrm{m}}\right)$ was found in a linear relationship with uniform water applied fraction in small experiment plots in either deficit $\left(1-\mu_{\mathrm{D}} / \mathrm{d}\right)$ or surplus $\left(\mu_{\mathrm{S}} / \mathrm{d}-1\right)$ irrigation conditions as shown in Fig. 6 . The relationship wasn't significantly changed under irrigation method or by season. Squash fruit yield reduction coefficients using regression as shown in Fig. 6 were, respectively, found as $0.81\left(\mathrm{k}_{\mathrm{y} 1}\right.$ with $\left.\mathrm{r}^{2}=0.96\right)$ and $0.54\left(\mathrm{k}_{\mathrm{y} 2}\right.$ with $\left.\mathrm{r}^{2}=0.93\right)$ in deficit and surplus irrigation conditions.

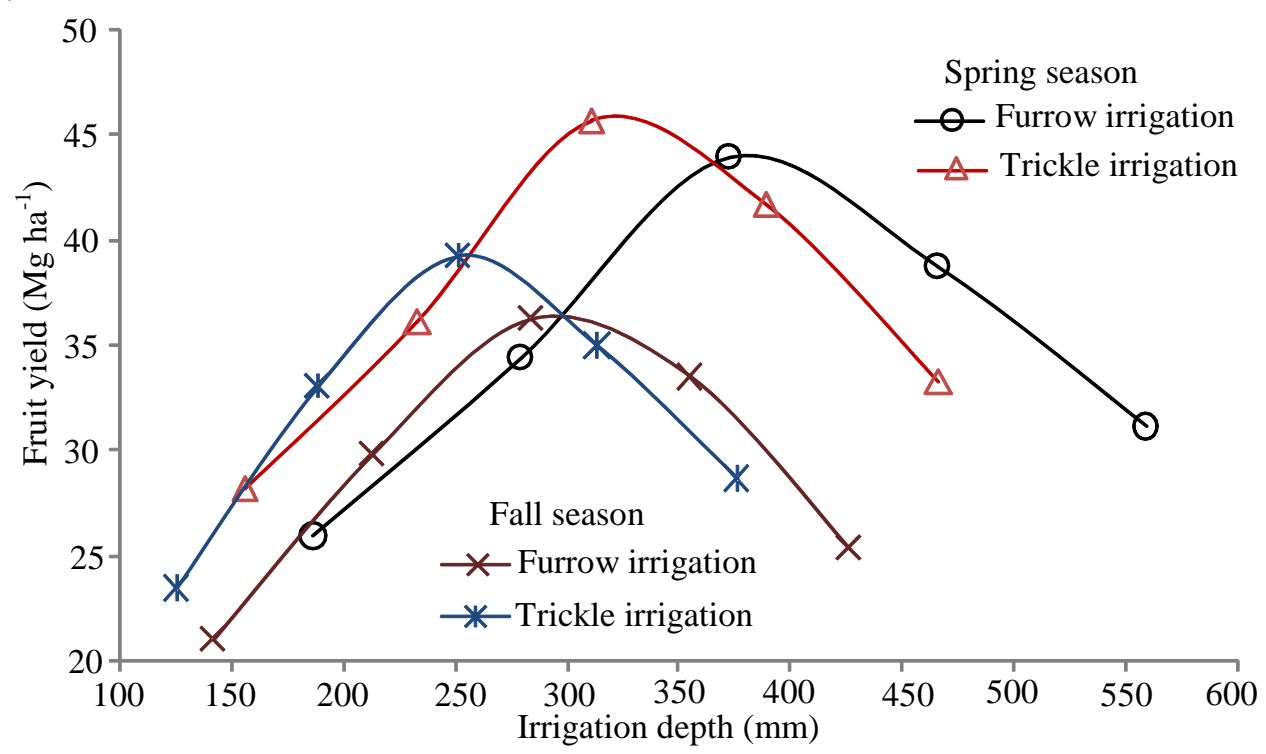

Fig. 5. Squash fruit yield-water function in 2010 spring and fall growing seasons.

\subsection{Fresh fruit production and quality}

Fruit yield, TSS, and harvest index showed significant differences between spring and fall seasons (Tables 4 and 5) due to decreasing weather elements at the end of the fall growing season. Moreover, they were significantly affected by irrigation method (I) and quantity $\left(\mathrm{ET}_{\mathrm{c}}\right)$. The results in Table 5 showed no interactions occurred among treatments, except between season and $\mathrm{ET}_{\mathrm{c}}$ for TSS. Under trickle method in spring season, maximum fruit yield (45.677 $\mathrm{Mg} \mathrm{h}^{-1}$ ) and TSS $(114 \mathrm{~g})$ were obtained for 1.0ET treatment, but maximum HI $(22.7 \%)$ was occurred for $0.75 \mathrm{ET}_{\mathrm{c}}$ and even that had no significant difference 
with $\mathrm{HI}$ obtained by1.0 $\mathrm{ET}_{\mathrm{c}}$ treatment. Therefore, $1.0 \mathrm{ET}_{\mathrm{c}}$ treatment was recommended under selected irrigation method and season in uniformity of irrigation application.

Table 4. Means and standard errors for fresh yield, harvest index (HI), plant dry matter and its components (TSS), and leaf area index (LAI).

\begin{tabular}{|c|c|c|c|c|}
\hline \multirow[b]{2}{*}{ Items } & \multicolumn{4}{|c|}{ Mean \pm SE } \\
\hline & \multirow{2}{*}{$\begin{array}{c}\text { Yield } \\
\left(\mathrm{Mg} \mathrm{ha}^{-1}\right)\end{array}$} & \multirow{2}{*}{$\begin{array}{l}\mathrm{HI} \\
(\%)\end{array}$} & \multirow{2}{*}{$\begin{array}{l}\text { TSS } \\
(\mathrm{g})\end{array}$} & \multirow{2}{*}{$\begin{array}{c}\text { LAI } \\
\left(\mathrm{m}^{3} \mathrm{~m}^{-3}\right)\end{array}$} \\
\hline$\underline{\text { Season }}$ & & & & \\
\hline$\overline{\text { Spring }}$ & $35.92 \pm 0.51^{\mathrm{B} \dagger}$ & $18.83 \pm 0.54^{\mathrm{B}}$ & $84.72 \pm 0.97^{\mathrm{A}}$ & $2.74 \pm 0.04^{\mathrm{A}}$ \\
\hline Fall & $30.54 \pm 0.51^{\mathrm{A}}$ & $15.06 \pm 0.54^{\mathrm{A}}$ & $90.55 \pm 0.97^{\mathrm{B}}$ & $3.08 \pm 0.04^{\mathrm{B}}$ \\
\hline \multicolumn{5}{|c|}{ Irrigation method (I) } \\
\hline Trickle & $34.44 \pm 0.51^{\mathrm{B}}$ & $17.74 \pm 0.54^{\mathrm{B}}$ & $94.04 \pm 0.97^{\mathrm{B}}$ & $3.05 \pm 0.04^{\mathrm{B}}$ \\
\hline Furrow & $32.02 \pm 0.51^{\mathrm{A}}$ & $16.16 \pm 0.54^{\mathrm{A}}$ & $81.23 \pm 0.97^{\mathrm{A}}$ & $2.77 \pm 0.04^{\mathrm{A}}$ \\
\hline \multicolumn{5}{|c|}{ Crop evapotranspiration $\left(\mathrm{ET}_{\mathrm{c}}\right)$} \\
\hline $0.5 \mathrm{ET}_{\mathrm{c}}$ & $24.64 \pm 0.81^{\mathrm{A}}$ & $15.89 \pm 0.86^{\mathrm{AB}}$ & $68.45 \pm 1.53^{\mathrm{A}}$ & $2.15 \pm 0.06^{\mathrm{A}}$ \\
\hline $0.75 \mathrm{ET}_{\mathrm{c}}$ & $33.36 \pm 0.81^{\mathrm{C}}$ & $19.30 \pm 0.86^{\mathrm{C}}$ & $79.14 \pm 1.53^{\mathrm{B}}$ & $2.53 \pm 0.06^{\mathrm{B}}$ \\
\hline $1.0 \mathrm{ET}_{\mathrm{c}}$ & $41.30 \pm 0.81^{\mathrm{E}}$ & $18.42 \pm 0.86^{\mathrm{BC}}$ & $105.58 \pm 1.53^{\mathrm{E}}$ & $2.79 \pm 0.06^{\mathrm{C}}$ \\
\hline $1.25 \mathrm{ET}_{\mathrm{c}}$ & $37.24 \pm 0.81^{\mathrm{D}}$ & $16.29 \pm 0.86^{\mathrm{AB}}$ & $101.94 \pm 1.53^{\mathrm{D}}$ & $3.49 \pm 0.06^{\mathrm{D}}$ \\
\hline $1.5 \mathrm{ET}_{\mathrm{c}}$ & $29.62 \pm 0.81^{\mathrm{B}}$ & $14.94 \pm 0.86^{\mathrm{A}}$ & $83.06 \pm 1.53^{C}$ & $3.58 \pm 0.06^{\mathrm{D}}$ \\
\hline
\end{tabular}

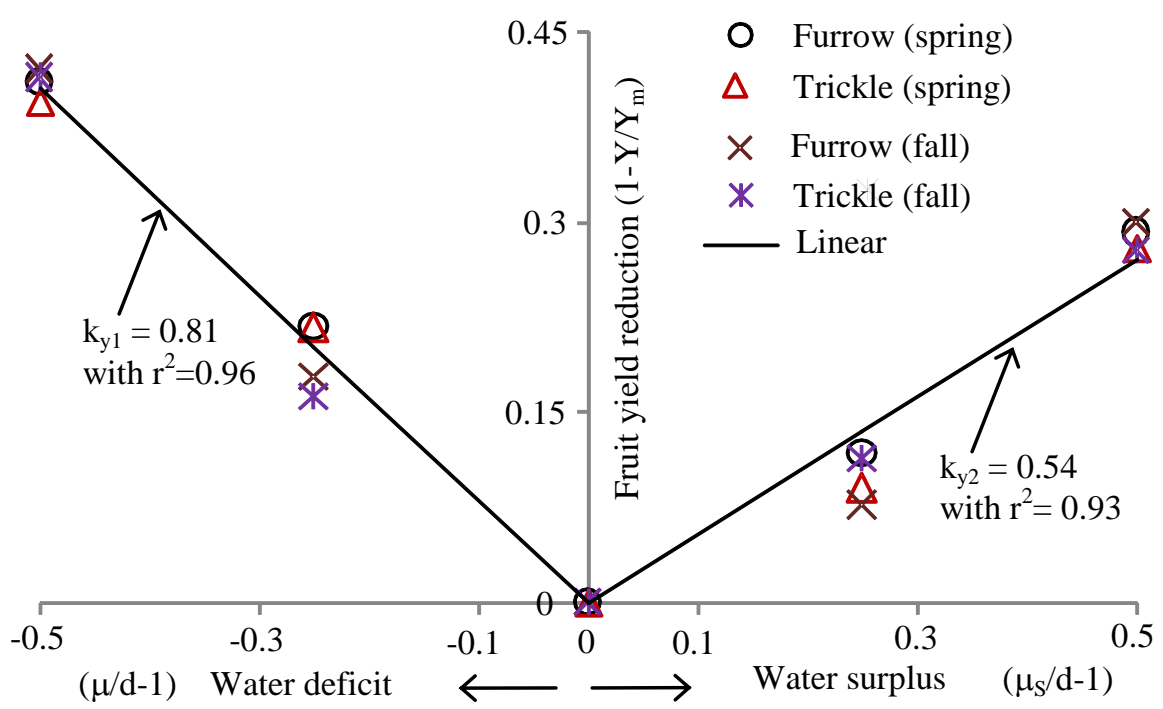

Fig. 6. Squash fruit yield reduction against water deficit or surplus. 
Table 5. Mean square, F value, and probability for fresh fruit yield, harvest index (HI), plant dry matter and its components (TSS), and leaf area index (LAI).

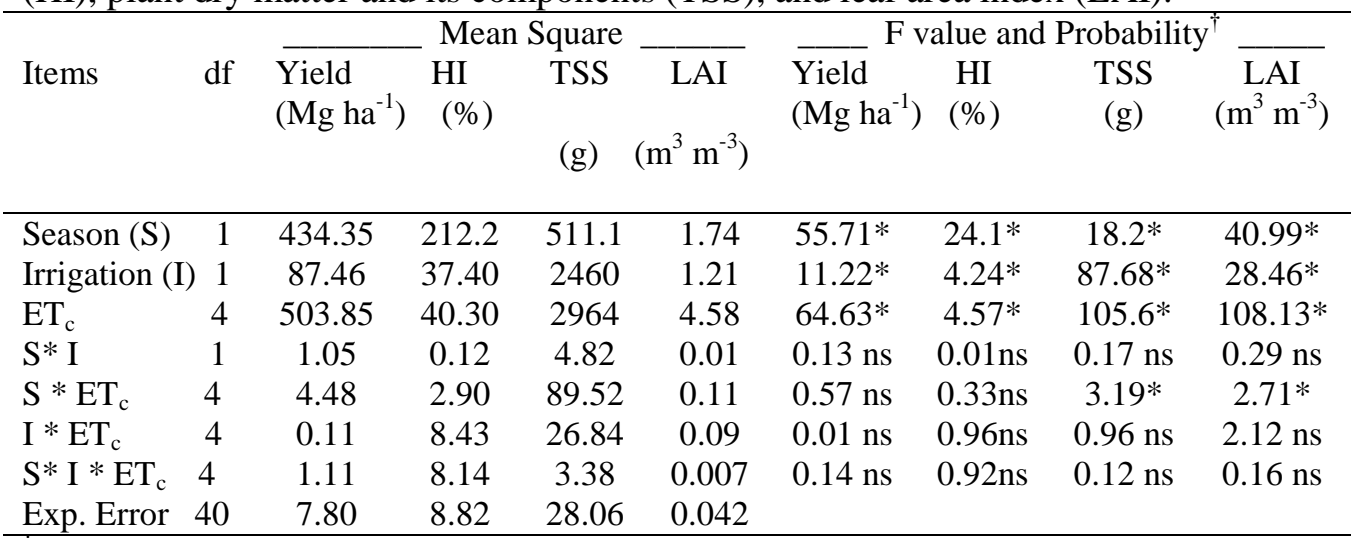

* Significant at the $\mathrm{p} \leq 0.05$ level. ns $=$ nonsignificant.

Table 6. Means and standard errors for squash fresh fruit weight, number, diameter, and length.

\begin{tabular}{|c|c|c|c|c|}
\hline \multirow[b]{2}{*}{ Items } & \multicolumn{4}{|c|}{ Mean \pm SE } \\
\hline & \multirow{2}{*}{$\begin{array}{l}\text { Weight } \\
(\mathrm{g})\end{array}$} & \multirow{2}{*}{$\begin{array}{l}\text { Number } \\
\text { (fruit/m²) }\end{array}$} & \multirow{2}{*}{$\begin{array}{l}\text { Diameter } \\
(\mathrm{cm})\end{array}$} & \multirow{2}{*}{$\begin{array}{l}\text { Length } \\
(\mathrm{cm})\end{array}$} \\
\hline$\underline{\text { Season }}$ & & & & \\
\hline Spring & $86.83 \pm 1.32^{\mathrm{A} \dagger}$ & $40.37 \pm 0.62^{\mathrm{B}}$ & $3.19 \pm 0.02^{\mathrm{A}}$ & $12.6 \pm 0.08^{\mathrm{A}}$ \\
\hline Fall & $98.52 \pm 1.32^{\mathrm{B}}$ & $30.37 \pm 0.62^{\mathrm{A}}$ & $3.41 \pm 0.02^{\mathrm{B}}$ & $12.5 \pm 0.08^{\mathrm{A}}$ \\
\hline \multicolumn{5}{|c|}{ Irrigation method (I) } \\
\hline Trickle & $94.82 \pm 1.32^{\mathrm{B}}$ & $35.17 \pm 0.62^{\mathrm{A}}$ & $3.33 \pm 0.02^{\mathrm{B}}$ & $12.71 \pm 0.08^{\mathrm{B}}$ \\
\hline Furrow & $90.53 \pm 1.32^{\mathrm{A}}$ & $35.57 \pm 0.62^{\mathrm{A}}$ & $3.26 \pm 0.02^{\mathrm{A}}$ & $12.41 \pm 0.08^{\mathrm{A}}$ \\
\hline \multicolumn{5}{|c|}{ Crop evapotranspiration $\left(\mathrm{ET}_{\mathrm{c}}\right)$} \\
\hline $0.5 \mathrm{ET}_{\mathrm{c}}$ & $81.61 \pm 2.08^{\mathrm{A}}$ & $29.50 \pm 0.98^{\mathrm{A}}$ & $3.14 \pm 0.03^{\mathrm{A}}$ & $12.13 \pm 0.13^{\mathrm{A}}$ \\
\hline $0.75 \mathrm{ET}_{\mathrm{c}}$ & $96.38 \pm 2.08^{\mathrm{B}}$ & $34.67 \pm 0.98^{\mathrm{B}}$ & $3.34 \pm 0.03^{\mathrm{C}}$ & $12.68 \pm 0.13^{\mathrm{B}}$ \\
\hline $1.0 \mathrm{ET}_{\mathrm{c}}$ & $103.76 \pm 2.08^{\mathrm{C}}$ & $39.75 \pm 0.98^{C}$ & $3.44 \pm 0.03^{\mathrm{D}}$ & $12.91 \pm 0.13^{\mathrm{B}}$ \\
\hline $1.25 \mathrm{ET}_{\mathrm{c}}$ & $97.41 \pm 2.08^{\mathrm{B}}$ & $38.25 \pm 0.98^{\mathrm{C}}$ & $3.35 \pm 0.03^{\mathrm{C}}$ & $12.84 \pm 0.13^{\mathrm{B}}$ \\
\hline $1.5 \mathrm{ET}_{\mathrm{c}}$ & $84.22 \pm 2.08^{\mathrm{A}}$ & $34.67 \pm 0.98^{\mathrm{B}}$ & $3.23 \pm 0.03^{\mathrm{B}}$ & $12.22 \pm 0.13^{\mathrm{A}}$ \\
\hline
\end{tabular}

Treatment means with the same letter are not significant at the $\mathrm{p} \leq 0.05$ level.

Fresh fruit weight, number, diameter, and length were statistically analyzed as shown in Tables 6 and 7. They were significantly affected by season and both irrigation method and quantity, except fruit length wasn't by season and number wasn't by irrigation method. The results in Table 7 showed no interactions occurred among treatments, except between season and $\mathrm{ET}_{\mathrm{c}}$ for fruit weight. For given irrigation method and season, fresh fruit weight, number, diameter, and length were higher when 
adequate irrigation was applied $\left(1.0 \mathrm{ET}_{\mathrm{c}}\right)$. Fruit weight, diameter, and length were highly achieved under trickle irrigation. Results were in accordance with those obtained by Malash et al. (2005) working on tomato who found that fruit weight, number, and TSS were increased under trickle method compared with furrow method. Moreover, Ozbahce and Tari (2010) found that fruit weight and diameter significantly affected by irrigation quantity under trickle irrigation.

Table 7. Mean square, F value, and probability for fresh fruit weight, number, diameter, and length.

\begin{tabular}{|c|c|c|c|c|c|c|c|c|c|}
\hline \multirow[b]{2}{*}{ Items } & \multirow[b]{2}{*}{$\mathrm{df}$} & \multicolumn{4}{|c|}{ Mean Square } & \multicolumn{4}{|c|}{ F value and Probability } \\
\hline & & $\begin{array}{l}\text { Weight } \\
\text { (g) }\end{array}$ & $\begin{array}{l}\text { Number } \\
\text { (fruit } / \mathrm{m}^{2} \text { ) }\end{array}$ & $\begin{array}{l}\text { Diamete } \\
(\mathrm{cm})\end{array}$ & $\begin{array}{r}r \text { Length } \\
(\mathrm{cm})\end{array}$ & $\begin{array}{l}\text { Weight } \\
\text { (g) }\end{array}$ & $\begin{array}{l}\text { Number } \\
\left(\text { fruit } / \mathrm{m}^{2}\right)\end{array}$ & $\begin{array}{l}\text { Diameter } \\
(\mathrm{cm})\end{array}$ & $\begin{array}{l}\text { Length } \\
(\mathrm{cm})\end{array}$ \\
\hline Season $(\mathrm{S})$ & 1 & 2050 & 1500 & 0.75 & 0.22 & $39.35^{*}$ & $130.2 *$ & $70.9 *$ & $1.03 \mathrm{~ns}$ \\
\hline Irrigation (I & 1 & 276.9 & 2.40 & 0.07 & 1.36 & $5.32 *$ & $0.21 \mathrm{~ns}$ & $6.84^{*}$ & $6.48 *$ \\
\hline $\mathrm{ET}_{\mathrm{c}}$ & 4 & 1059 & 188.8 & 0.16 & 1.54 & $20.33 *$ & $16.4^{*}$ & $15.5 *$ & $7.33^{*}$ \\
\hline $\mathrm{S} * \mathrm{I}$ & 1 & 12.97 & 3.27 & 0.02 & 0.51 & $0.25 \mathrm{~ns}$ & $0.28 \mathrm{~ns}$ & $2.4 \mathrm{~ns}$ & $2.44 \mathrm{~ns}$ \\
\hline $\mathrm{S} * \mathrm{ET}_{\mathrm{c}}$ & 4 & 175.9 & 22.96 & 0.02 & 0.33 & $3.38 *$ & $1.9 \mathrm{~ns}$ & $2.2 \mathrm{~ns}$ & $1.57 \mathrm{~ns}$ \\
\hline $\mathrm{I} * \mathrm{ET}_{\mathrm{c}}$ & 4 & 24.42 & 4.11 & 0.00 & 0.07 & $0.47 \mathrm{~ns}$ & $0.36 \mathrm{~ns}$ & $0.5 \mathrm{~ns}$ & $0.33 \mathrm{~ns}$ \\
\hline $\mathrm{S} * \mathrm{I} * \mathrm{ET}_{\mathrm{c}}$ & 4 & 23.82 & 5.06 & 0.00 & 0.15 & $0.46 \mathrm{~ns}$ & $0.44 \mathrm{~ns}$ & $0.13 n s$ & $0.70 \mathrm{~ns}$ \\
\hline Exp. Error & 40 & 52.09 & 11.52 & 0.01 & 0.21 & & & & \\
\hline
\end{tabular}

* Significant at the $\mathrm{p} \leq 0.05$ level.

ns $=$ non-significant

\subsection{Seed crop response}

Seed crop yield $\left(\mathrm{Mg} \mathrm{ha}^{-1}\right)$ increased as irrigation water applied $(\mathrm{mm})$ increased in deficit irrigation (from 0.5ET to 1.0ET); then, it decreased in surplus irrigation (from 1.0ET to 1.5ET) in both growing seasons (Fig. 7). For an adequate irrigation (1.0ET), maximum seed yield values were 0.928 and $0.838 \mathrm{Mg} \mathrm{ha}^{-1}$ in spring season and 0.506 and $0.441 \mathrm{Mg} \mathrm{ha}^{-1}$ in fall season under trickle and furrow methods, respectively. Seed yield was increased by $9.7 \%$ with $15.5 \%$ water saving in spring and $12.8 \%$ with $11.6 \%$ water saving in fall under trickle irrigation relative to that of furrow irrigation. Likewise, it was increased by $45.5 \%$ with $19.3 \%$ more water consumed under trickle irrigation and $37.4 \%$ with $22.8 \%$ more water consumed under furrow irrigation over spring growing season relative to that of fall season. The results showed that huge reduction of seed yield was occurred in fall season due to significant decrease in weather elements at the end of the season during seeds filling. These results are in agreement with those of Wan et al. (2010) working on cucumber who mentioned that the low yield was attributed to bad 
weather. For that reason, squash wasn't recommended to grow seed in fall season. A seed yield reduction $\left(1-\mathrm{Y}_{\mathrm{H}} \mathrm{Y}_{\mathrm{m}}\right)$, which insignificantly affected by both irrigation method and season, was found in a linear relationship with uniform water applied fraction in either deficit $\left(1-\mu_{D} / d\right)$ or surplus $\left(\mu_{\mathrm{S}} / \mathrm{d}-1\right)$ irrigation conditions as shown in Fig. 8. Squash seed yield reduction coefficients using regression as shown in Fig. 8 were, respectively, found as $0.774\left(\mathrm{k}_{\mathrm{y} 1}\right.$ with $\left.\mathrm{r}^{2}=0.91\right)$ and $0.293\left(\mathrm{k}_{\mathrm{y} 2}\right.$ with $\left.r^{2}=0.91\right)$ in deficit and surplus irrigation conditions.

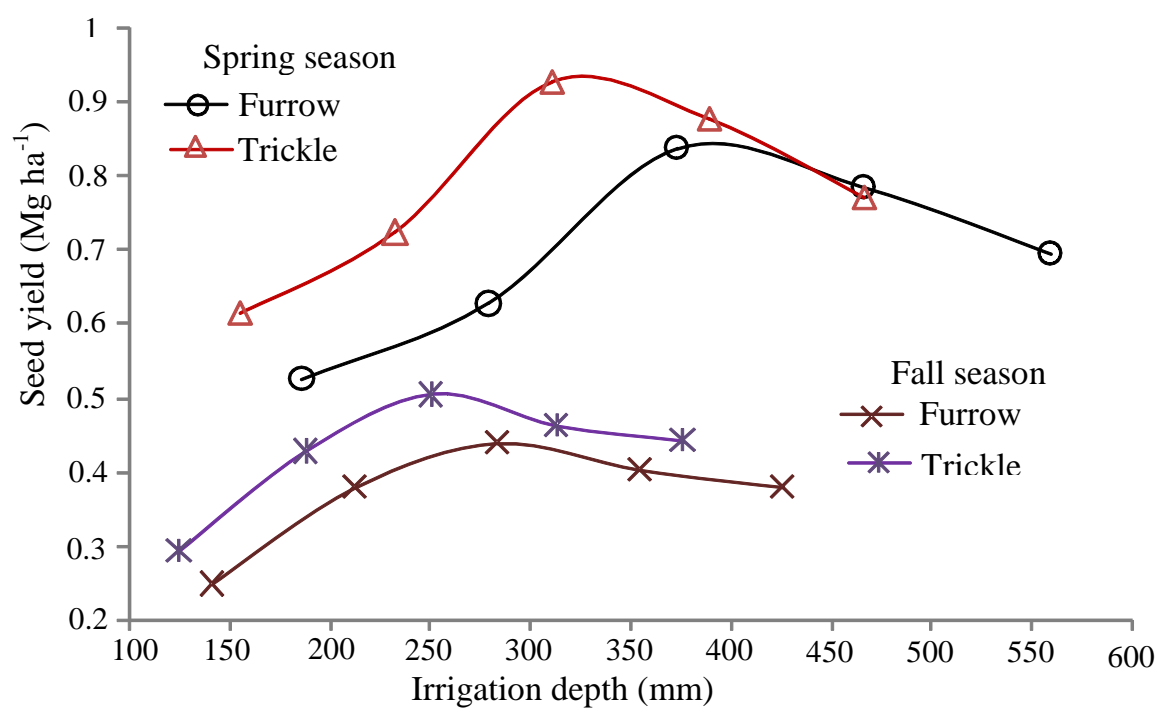

Fig. 7. Squash seed yield-water function in 2010 spring and fall growing seasons.

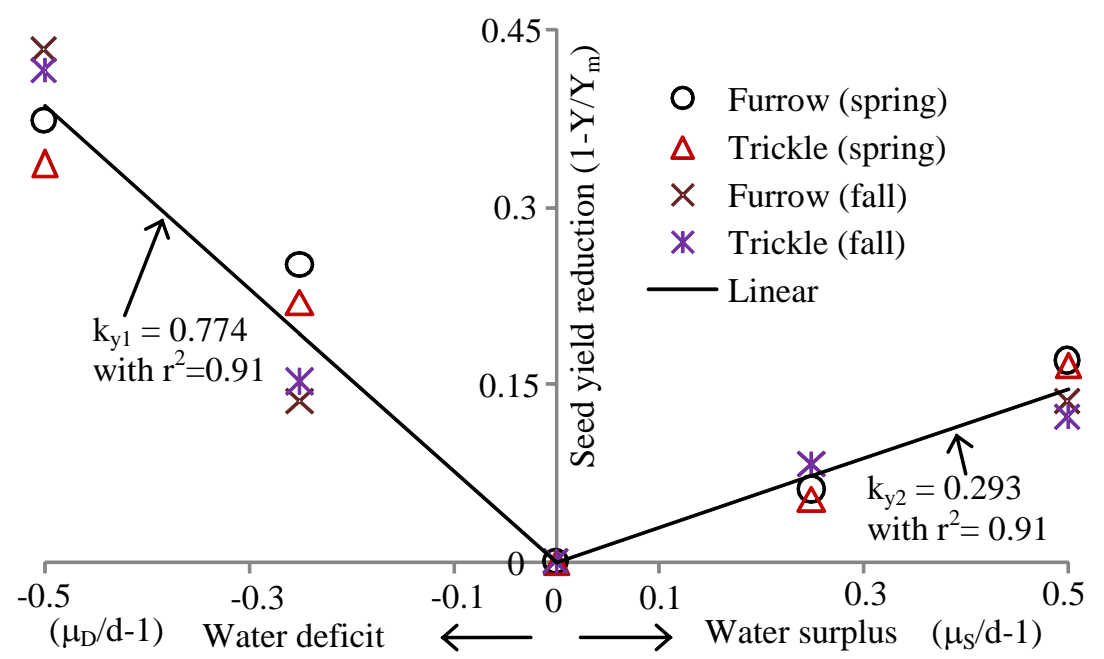

Fig. 8. Squash seed yield reduction against water deficit or surplus. 


\subsection{Seed production and quality}

Seed yield, harvest index (HI), plant TSS, 100 seeds weight, and seed germination percentage were significantly affected by season and both irrigation method and quantity (Tables 8 and 9), except HI wasn't by irrigation method. Squash seed parameters were greatly obtained by spring season, trickle method, and adequate irrigation quantity $\left(1.0 \mathrm{ET}_{\mathrm{c}}\right)$, except HI was highly achieved under trickle irrigation with $1.5 \mathrm{ET}_{\mathrm{c}}$ treatment in spring season. It seemed that high $\mathrm{HI}$ was achieved with 1.5 $\mathrm{ET}_{\mathrm{c}}$ treatment which was insignificant with $0.75 \mathrm{ET}_{\mathrm{c}}$ (Table 8) because of decreasing the dry weight of seed casing which was the more significant value. Only seed yield and 100 seeds weight showed interactions between season and irrigation method. Seed production and quality showed interactions between season and irrigation quantity $\left(\mathrm{ET}_{\mathrm{c}}\right)$, except HI wasn't. Only 100 seeds weight was significantly affected by the interaction between irrigation method and quantity. There weren't interactions among season and both irrigation method and quantity for seed production and quality. Results are in agreement with those obtained by Garcia et al. (2010) working on soybean who found that seed yield, LAI, and plant TSS were significantly affected by irrigation regimes.

Table 8. Means and standard errors for seed yield, harvest index (HI), plant dry matter and its components (TSS), leaf area index (LAI), 100 seeds weight, and germination percentage

\begin{tabular}{|c|c|c|c|c|c|c|}
\hline \multirow[b]{2}{*}{ Items } & \multicolumn{6}{|c|}{ Mean \pm SE } \\
\hline & \multirow{2}{*}{$\begin{array}{l}\text { Seed yield } \\
\left(\mathrm{Mg} \mathrm{ha}^{-1}\right)\end{array}$} & \multirow{2}{*}{$\begin{array}{l}\mathrm{HI} \\
(\%)\end{array}$} & \multirow{2}{*}{$\begin{array}{c}\text { TSS } \\
(\mathrm{g})\end{array}$} & \multirow{2}{*}{$\begin{array}{c}\text { LAI } \\
\left(\mathrm{m}^{3} \mathrm{~m}^{-3}\right)\end{array}$} & \multirow{2}{*}{$\begin{array}{l}100 \text { seeds } \\
\text { weight }(\mathrm{g})\end{array}$} & \multirow{2}{*}{$\begin{array}{c}\text { Germination } \\
(\%)\end{array}$} \\
\hline Season & & & & & & \\
\hline Spring & $0.74 \pm 0.003^{\mathrm{B}^{\dagger}}$ & $11.81 \pm 0.1^{\mathrm{B}}$ & $156.9 \pm 1.41^{\mathrm{B}}$ & $2.62 \pm 0.04^{\mathrm{B}}$ & $15.8 \pm 0.07^{\mathrm{B}}$ & $86.4 \pm 041^{\mathrm{B}}$ \\
\hline Fall & $0.40 \pm 0.003^{\mathrm{A}}$ & $6.78 \pm 0.1^{\mathrm{A}}$ & $147.6 \pm 1.41^{\mathrm{A}}$ & $2.99 \pm 0.04^{\mathrm{A}}$ & $10.2 \pm 0.07^{\mathrm{A}}$ & $51.3 \pm 0.41^{\mathrm{A}}$ \\
\hline \multicolumn{7}{|c|}{ Irrigation method (I) } \\
\hline Trickle & $0.61 \pm 0.003^{\mathrm{B}}$ & $38 \pm 0.1^{\mathrm{A}}$ & $160.4 \pm 1.41^{\mathrm{B}}$ & $3.01 \pm 0.04^{\mathrm{B}}$ & $13.7 \pm 0.07^{\mathrm{B}}$ & $76.8 \pm 0.41^{\mathrm{B}}$ \\
\hline Furrow & $0.53 \pm 0.003^{\mathrm{A}}$ & $9.2 \pm 0.1^{\mathrm{A}}$ & $144.1 \pm 1.41^{\mathrm{A}}$ & $2.60 \pm 0.04^{\mathrm{A}}$ & $12.3 \pm 0.07^{\mathrm{A}}$ & $71.9 \pm 0.41^{\mathrm{A}}$ \\
\hline \multicolumn{7}{|c|}{ Evapotranspiration (ET) } \\
\hline $0.5 \mathrm{ET}$ & $0.42 \pm$ & $8.76 \pm 0.15^{\mathrm{A}}$ & $.6 \pm 2.23^{\mathrm{A}}$ & $2.09 \pm 0.06^{\mathrm{A}}$ & $10.2 \pm 0.11^{\mathrm{A}}$ & $61.2 \pm 0.64^{\mathrm{A}}$ \\
\hline $0.75 \mathrm{ET}$ & $0.54 \pm 0.005^{\mathrm{B}}$ & $9.70 \pm 0.15^{\mathrm{B}}$ & $139.3 \pm 2.23^{\mathrm{B}}$ & $2.53 \pm 0.06^{\mathrm{B}}$ & $12.8 \pm 0.11^{\mathrm{C}}$ & $77.8 \pm 0.64^{\mathrm{C}}$ \\
\hline 1.0ET & $0.68 \pm 0.005^{\mathrm{E}}$ & $9.15 \pm 0.15^{\mathrm{A}}$ & $182.8 \pm 2.23^{\mathrm{D}}$ & $2.72 \pm 0.06^{\mathrm{C}}$ & $15.8 \pm 0.11^{\mathrm{E}}$ & $83.2 \pm 0.64^{\mathrm{D}}$ \\
\hline $1.25 \mathrm{ET}$ & $0.63 \pm 0.005^{\mathrm{D}}$ & $9.03 \pm 0.15^{\mathrm{A}}$ & $174.0 \pm 2.23^{\mathrm{C}}$ & $3.34 \pm 0.06^{\mathrm{D}}$ & $14.2 \pm 0.11^{\mathrm{D}}$ & $79.0 \pm 0.64^{\mathrm{C}}$ \\
\hline $1.5 \mathrm{ET}$ & $0.58 \pm 0.005^{\mathrm{C}}$ & $9.85 \pm 0.15^{\mathrm{B}}$ & $145.5 \pm 2.23^{\mathrm{B}}$ & $3.35 \pm 0.06^{\mathrm{D}}$ & $12.0 \pm 0.11^{\mathrm{B}}$ & $74.4 \pm 0.64^{\mathrm{B}}$ \\
\hline
\end{tabular}

${ }^{\dagger}$ Treatment means with the same letter are not significant at the $\mathrm{p} \leq 0.05$ level. 
Table 9. Mean square, F value, and probability for seed yield, harvest index (HI), plant dry matter and its components (TSS), leaf area index (LAI), 100 seeds weight, and germination.

\begin{tabular}{|c|c|c|c|c|c|c|c|}
\hline \multirow[b]{2}{*}{ Items } & \multirow[b]{2}{*}{ df } & \multicolumn{6}{|c|}{ Mean Square } \\
\hline & & $\begin{array}{c}\text { Yield } \\
\left(\mathrm{Mg} \mathrm{ha}^{-1}\right)\end{array}$ & $\begin{array}{l}\mathrm{HI} \\
(\%)\end{array}$ & $\begin{array}{l}\text { TSS } \\
(\mathrm{g})\end{array}$ & $\begin{array}{c}\text { LAI } \\
\left(\mathrm{m}^{3} \mathrm{~m}^{-3}\right)\end{array}$ & $\begin{array}{l}100 \text { seeds } \\
\text { weight }(\mathrm{g})\end{array}$ & $\begin{array}{c}\text { Germination } \\
(\%)\end{array}$ \\
\hline Season $(\mathrm{S})$ & 1 & 1.72 & 378.8 & 1309.1 & 2.102 & 458.5 & 8808.8 \\
\hline Irrigation (I) & 1 & 0.077 & 0.41 & 3995.7 & 2.457 & 28.95 & 360.15 \\
\hline ET & 4 & 0.113 & 2.54 & 8047.1 & 3.505 & 55.31 & 847.07 \\
\hline$S^{*} \mathrm{I}$ & 1 & 0.01 & 0.22 & 9.15 & 0.002 & 1.12 & 18.15 \\
\hline $\mathrm{S} * \mathrm{ET}$ & 4 & 0.011 & 0.73 & 173.4 & 0.161 & 3.85 & 28.567 \\
\hline $\mathrm{I} * \mathrm{ET}$ & 4 & $5 \mathrm{E}-05$ & 0.33 & 65.75 & 0.080 & 6.97 & 2.4 \\
\hline $\mathrm{S} * \mathrm{I} * \mathrm{ET}$ & 4 & 2E-04 & 0.03 & 9.86 & 0.023 & 0.08 & 7.7333 \\
\hline \multirow[t]{2}{*}{ Exp. Error } & 40 & $3 \mathrm{E}-04$ & 0.29 & 60.04 & 0.046 & 0.15 & 4.95 \\
\hline & \multicolumn{7}{|c|}{ F value and Probability ${ }^{\dagger}$} \\
\hline Season (S) & & $6303 *$ & $1324 *$ & $21.8 *$ & $45.91 *$ & $3152.3 *$ & $1779.6 *$ \\
\hline Irrigation (I) & & $281.5^{*}$ & $1.42 \mathrm{~ns}$ & $66.6^{*}$ & $53.64 *$ & $199.1^{*}$ & $72.76^{*}$ \\
\hline ET & & $414.3^{*}$ & $8.89 *$ & $134 *$ & $76.54 *$ & $380.3 *$ & $171.1 *$ \\
\hline $\mathrm{S}^{*} \mathrm{I}$ & & $22.25^{*}$ & $0.78 \mathrm{~ns}$ & $0.153 \mathrm{~ns}$ & $0.05 \mathrm{~ns}$ & $7.67 *$ & $3.67 \mathrm{~ns}$ \\
\hline$S * E T$ & & $39.88 *$ & $2.54 \mathrm{~ns}$ & $2.89 *$ & $3.52 *$ & $26.49^{*}$ & $5.77 *$ \\
\hline $\mathrm{I} * \mathrm{ET}$ & & $0.19 \mathrm{~ns}$ & $1.16 \mathrm{~ns}$ & $1.10 \mathrm{~ns}$ & $1.74 \mathrm{~ns}$ & $47.92 *$ & $0.485 \mathrm{~ns}$ \\
\hline $\mathrm{S} * \mathrm{I} * \mathrm{ET}$ & & $0.63 \mathrm{~ns}$ & $0.10 \mathrm{~ns}$ & $0.16 \mathrm{~ns}$ & $0.50 \mathrm{~ns}$ & $0.54 \mathrm{~ns}$ & $1.56 \mathrm{~ns}$ \\
\hline
\end{tabular}

"* Significant at the $\mathrm{p} \leq 0.05$ level.

ns $=$ nonsignificant

\subsection{Optimal irrigation scheduling under non-uniformity of irrigation}

Squash crop response obtained from uniformity condition (experiment) was extrapolated to non-uniformity condition (big field) using Eq. 3. Non-uniformity of irrigation conditions were selected as $0.1,0.2$, and 0.3 coefficient of variation which was almost appropriated to the range of irrigation water applied in the experiment (from 0.5 to $1.5 \mathrm{ET}_{\mathrm{c}}$ ). Using the foregoing parameters $\mathrm{k}_{\mathrm{y} 1}$ and $\mathrm{k}_{\mathrm{y} 2}$ which were found as 0.81 and 0.54 for fruit yield and 0.774 and 0.293 for seed yield, respectively, the relationship between squash relative fruit and seed yields $\left(\mathrm{Y} / \mathrm{Y}_{\mathrm{m}}\right)$ and relative irrigation depths $(d / \mu)$ for different $C V$ values was shown in Fig. 9. Non-uniformity application which included both water deficit and surplus started from $0.828,0.655$, and $0.483 \mathrm{~d} / \mu_{\max }$ (complete surplus) and ended to $1.172,1.345$, and $1.517 \mathrm{~d} / \mu_{\min }$ (complete deficit) for 0.1 , 0.2 , and 0.3 coefficient of variation, respectively. Relative yield was significantly affected by both $d / \mu$ and $C V$ in non-uniformity irrigation, but, it was significantly changed only by $d / \mu$ in uniformity irrigation. The 
results showed that uniformity was an insignificant parameter when too little water or too much water was applied in either deficit or surplus irrigations. For example, when $\mathrm{CV}$ was equal to 0.3, the significant of uniformity was only in a range of $\mathrm{d} / \mu$, between 0.483 and 1.517 , and beyond that range it was insignificant. Optimum relative irrigation depths $(d / \mu)$ that achieved maximum yield were found as $0.980,0.991$, and 1.03 for fruit yield and $0.831,0.799$, and 0.796 for seed yield at the CV values as $0.1,0.2$, and 0.3 , respectively. These results showed significant differences among optimum depths obtained for fruit and seed productions due to increasing yield reduction coefficients $\left(\mathrm{k}_{\mathrm{y} 1}, \mathrm{k}_{\mathrm{y} 2}\right.$, and principally $\mathrm{k}_{\mathrm{y} 2}$ ) for fruit yield relative to those of seed yield. Thus, optimum $\mathrm{d} / \mu$ was around one for fruit yield and around 0.81 for seed yield. It was evident that yield reduction coefficients $\left(\mathrm{k}_{\mathrm{y} 1}\right.$ and $\left.\mathrm{k}_{\mathrm{y} 2}\right)$ with system's $\mathrm{CV}$ are the factors that diverge the optimum relative irrigation depth $(\mathrm{d} / \mu)$ from the integral one. When $\mathrm{k}_{\mathrm{y} 1}$ and $\mathrm{k}_{\mathrm{y} 2}$ come closer $\mathrm{CV}$ becomes insignificant. These conclusions are in agreement with those of Wu and Barragan (2000), Amer et al. (2009), and Amer (2010) using cumulative linear distribution.

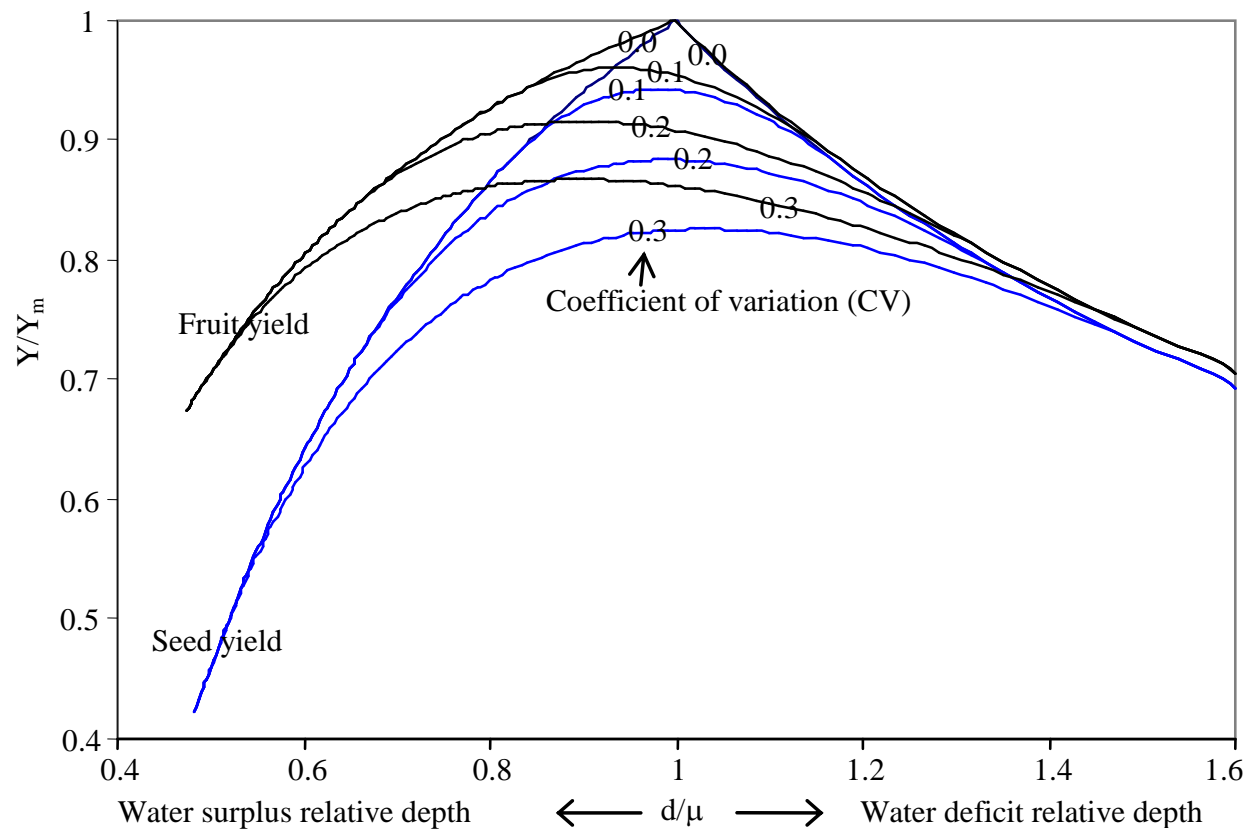

Fig. 9. Predicted squash relative fruit and seed yields $\left(Y / Y_{m}\right)$ vs. relative irrigation depth $(d / \mu)$. 


\section{CONCLUSION}

The effect of irrigation method and quantity combinations needs to be known in the management of water, crop, season, and soil. A field experiment was conducted using squash grown in 2010 spring and fall seasons to evaluate different irrigation applications under both trickle and furrow irrigation methods. Five irrigation levels $(0.5,0.75,1.0,1.25$, and $1.5 \mathrm{ET}_{\mathrm{c}}$ ) were arranged in a randomized split-plot design with irrigation method as main plots and irrigation levels within each method. Results showed that water applied and used for squash were significantly reduced by either trickle method or fall season, relative to those obtained by either furrow method or spring season. In well-watered condition, squash crop coefficient was significantly reduced under trickle irrigation compared with furrow in early vegetative stage due to increasing soil evaporation along furrow, but insignificantly in both full vegetative and maturity stages.

Squash fruit and seed yields were significantly higher by spring season, trickle irrigation, and adequate irrigation. The results showed that huge reduction of seed yield (41\%) occurred in fall season compared with spring season due to significant decrease in weather elements at the end of the season during seeds filling. For that reason, squash wasn't recommended to produce seed in fall season.

Squash fruit yield and its plant TSS, harvest index (HI), and leaf area index (LAI) showed significant differences by season and both irrigation method and quantity. Under trickle method in spring season, maximum fruit yield (45.677 $\mathrm{Mg} \mathrm{h}^{-1}$ ) and plant TSS (114 g) were obtained for 1.0 $\mathrm{ET}_{\mathrm{c}}$ treatment, but maximum LAI (3.45) was occurred for $1.5 \mathrm{ET}_{\mathrm{c}}$ and $\mathrm{HI}$ $(22.7 \%)$ was for $0.75 \mathrm{ET}_{\mathrm{c}}$, the latter had insignificant difference with that of 1.0 $\mathrm{ET}_{\mathrm{c}}$ treatment. For given irrigation method and season, fresh fruit weight, number, diameter, and length were higher when adequate irrigation was applied $\left(1.0 \mathrm{ET}_{\mathrm{c}}\right)$. Fruit weight, diameter, and length were highly achieved under trickle irrigation. Seed yield and its HI, plant TSS, LAI, 100 seeds weight, and seed germination percentage were significantly affected by season and both irrigation method and quantity, except HI wasn't by irrigation method. Squash seed parameters were greatly obtained by spring season, trickle method, and adequate irrigation quantity $\left(1.0 \mathrm{ET}_{\mathrm{c}}\right)$, except $\mathrm{HI}$ and LAI was highly achieved under trickle 
irrigation with $1.5 \mathrm{ET}_{\mathrm{c}}$ treatment. Therefore, $1.0 \mathrm{ET}_{\mathrm{c}}$ treatment was recommended under selected irrigation method and season in uniform of irrigation application.

Squash relative yield and its relative scheduling depth were predicted in non-uniformity condition by extrapolating the data from uniformity condition (small experiment). Optimum irrigation scheduling depths as well as their corresponding yield were significantly changed by both nonuniformity condition and crop yield reduction coefficients.

\section{REFERENCES}

Ahmet, E., Sensoy, S., Kucukyumuk, C., Gedik. I., 2004. Irrigation frequency and amount affect yield components of spring squash (Cucurbita pepo L.). Agric. Water Mgt. 67: 63-76.

Al-Omran, A.M., Shetaa, A.S., Falataha, A.M., Al-Harbi, A.R., 2005. Effect of drip irrigation on squash (Cucurbita pepo) yield and water-use efficiency in sandy calcareous soils amended with clay deposits. Agric. Water Mgt. 73: 43-55.

Allen, R.G, Pereira, L.S., Raes, D., Smith, M., 1998. Crop evapotranspiration guidelines for computing crop water requirements. FAO Irrig. and Drain. Paper 56, United Nations, Rome, Italy: 30-42.

Amer, K., Hatfield, J.L., 2004. Canopy resistance as affected by soil and meteorological parameters in potato. Agron. J. 96:978-985.

Amer, K.H., Medan, S.A., Hatfield, J.L., 2009. Effect of deficit irrigation and fertilization on cucunber. Agron. J. 101(6): 1556-1564.

Amer, K.H. (2010). Corn crop response under managing different irrigation and salinity levels. Agr. Water Manage., (97): 1553-1663.

Garcia, A.G., Persson, T., Guerra, L.C., Hoogenboom, G., 2010. Response of soybean genotypes to different irrigation regimes in a humid region of the southeastern USA. Agr. Water Manage., (97): 981-987.

Hassanli, A.M., S. Ahmadirad, S. Beecham (2010). Evaluation of the influence of irrigation methods and water quality on sugar beet yield and water use efficiency. Agr. Water Manage., (97): 357-362.

Malash, N., Flowers, T.J., Ragab, R., .2005. Effect of irrigation systems and water management practices using saline and non-saline water on tomato production. Agr. Water Manage., (78): 25-38. 
Mario, H., Bill, M., Jason, S., John, S., 1997. Oregon State University Western Oregon Squash Irrigation Guide, vol. 541. Department of Bioresource Engineering, 116 Gilmore Hall, Corvallis, pp. 7376304 (OR 97331-3906).

Ozbahce, A., Tari, A.F., (2010). Effects of different emitter space and water stress on yield and quality of processing tomato under semiarid climate conditions. Agr. Water Manage., (97): 1405-1410.

Richard, M., Jose, A., Mark, G., Keith, M., 2002. Spring Squash Production in California. Vegetable Research and Information Center, Vegetable Reproduction Series, California, Publication 7245 .

Statistical Analysis System (SAS), 2003. User's Guide, Institute, Carry, North Carolina.

Wan, S., Kang, Y., Wang, D., Liu, S., 2010. Effect of saline water on cucumber (Cucumis sativus L.) yield and water use under drip irrigation in North China. Agr. Water Manage., (98): 105-113.

Wu, I.P., Barragan, J., 2000. Design criteria for microirrigation systems. Trans. of the ASAE. 43(5): 1145-43(5):1145-115.

\section{الملخص العربيى \\ تأثير طريقة وكمية الري على محصول الكوسة وجودته كمال حسني حنفي عامر}

تتأثر المحاصيل الزر اعية ونوعية إنتاجها بكل من كمية ونظـام الري وموسم الزر اعـة والتربـة

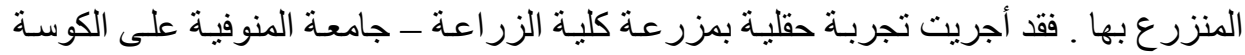

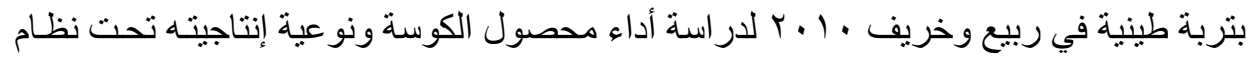

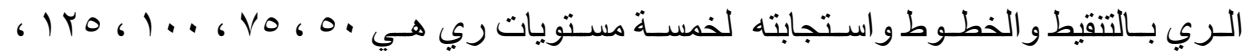

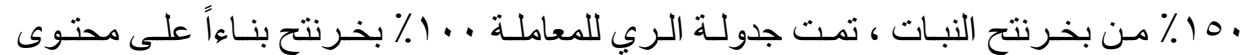
الرطوبة للتربة لكل نظام ري على حدا ثم حسـاب النسب الأخرى لمستويات الري. تم تصميم

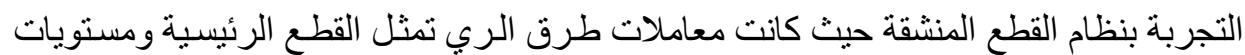

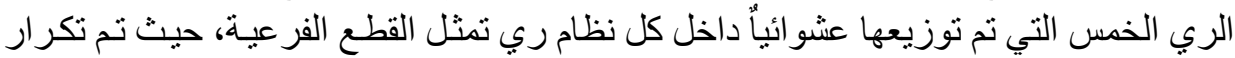

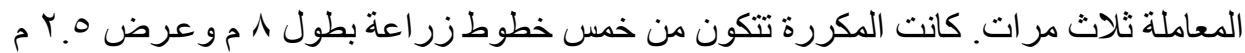

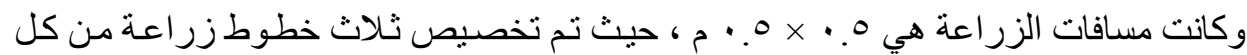

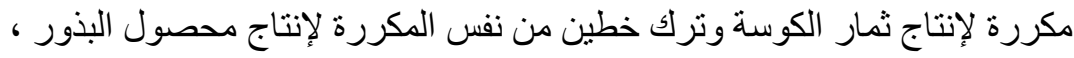




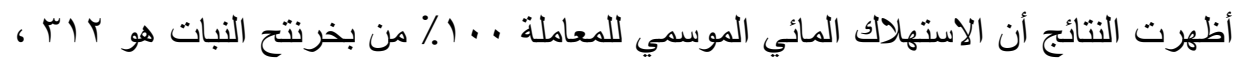

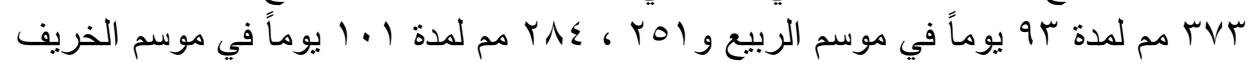

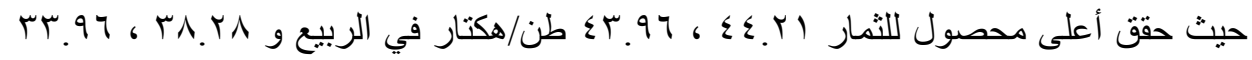

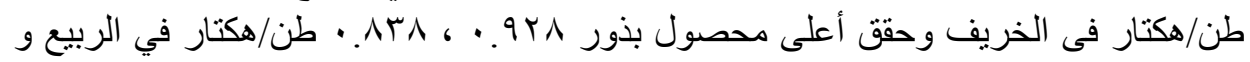

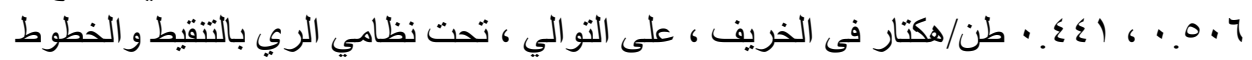

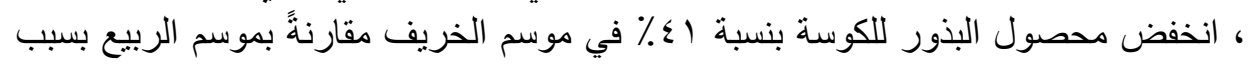

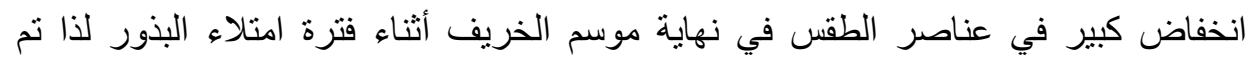

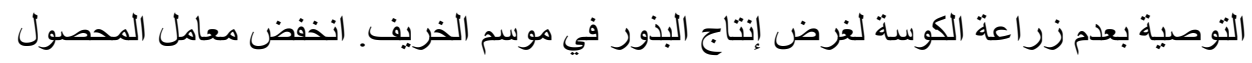

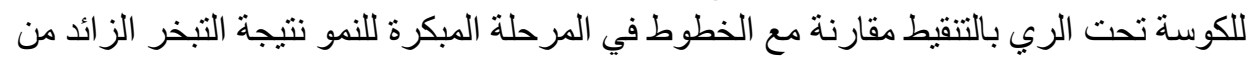

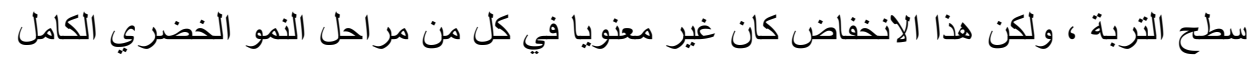

أظهر كل من محصول الثمار للكوسة والوزن الجاف للنبات ومكوناته ودليلي الحصاد و المساحة الورقة فروقاً معنويةٌٌ لموسمي الزر اعة ونظام وكميات الري، حيث كان أعلى قيم تم

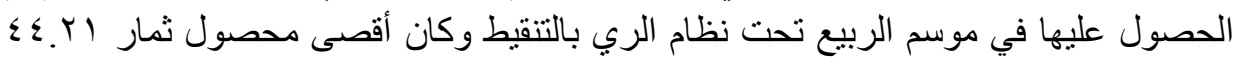

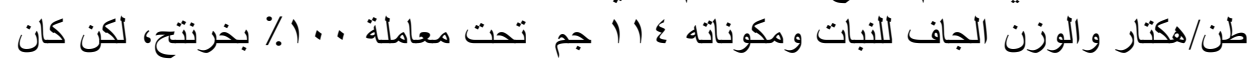

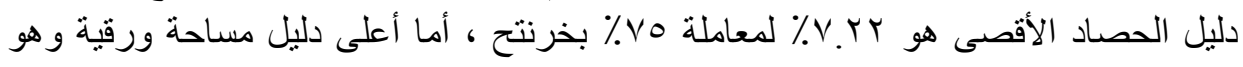

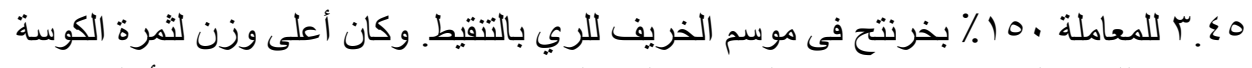

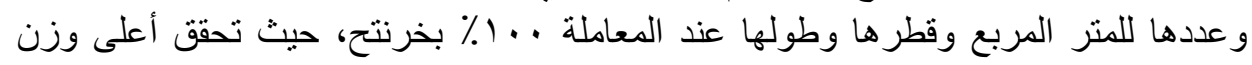

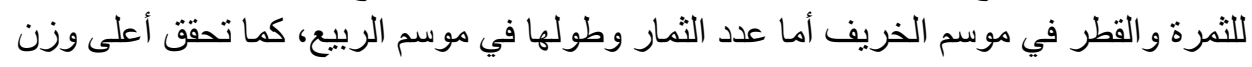
لثمرة الكوسة وقطر ها وطو لها تحت نظام الري بالتنقيط.

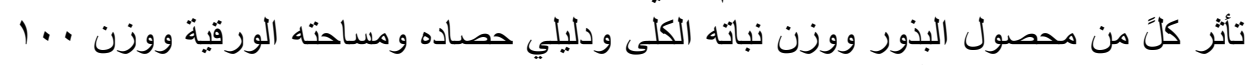

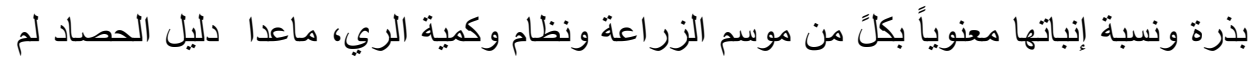

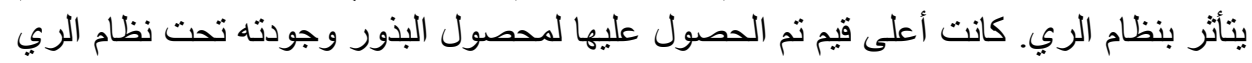

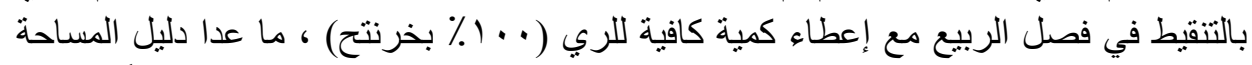

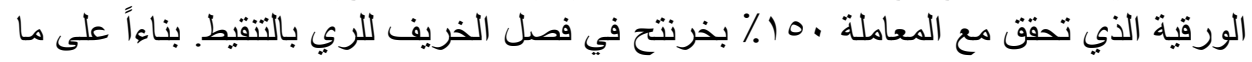

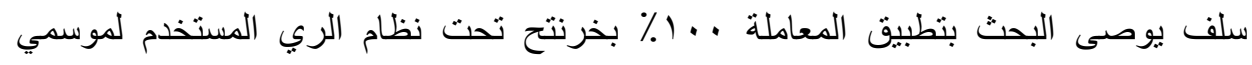
الزر اعة في حالة انتظامية توزيع مياه الري، ماعدا موسم الخريف في إنتاج محصول البحنة البذور.

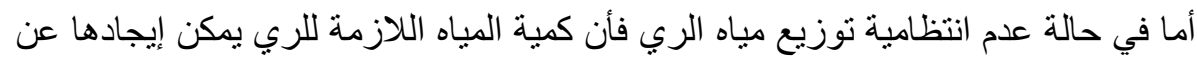

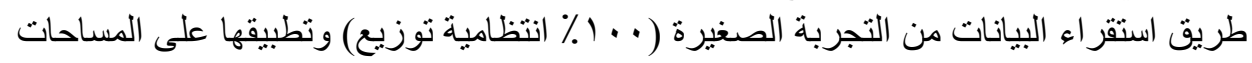
الكبيرة التي تروى بأنظمة الري والتي توزع المياه بدرجات انتظامبة مختلفة و التي يمكن تقدير ها

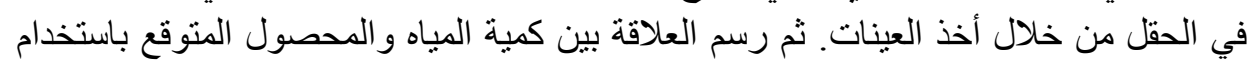

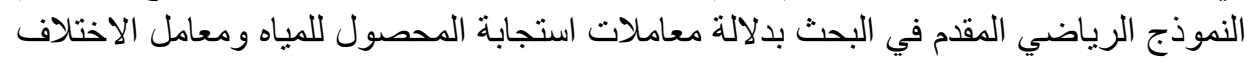
ألتوزيعي للمياه وبالتالي يمكن الحصول على كميات المياه المثلي اللازمة لمعظمة إنتاجية المحاصيل تحت كل درجة اختلاف نوزيعي لمياه الري بمعلومية معامل المحصول والبخرنتح القياسي بالمنطقة تحت كل نظام ري. 